\title{
LOS COMIENZOS DE LA COMPAÑÍA DE JESÚS EN EL PERÚ Y SU CONTEXTO POLÍTICO Y RELIGIOSO: LA FIGURA DE LUIS LÓPEZ
}

\author{
POR \\ FERNANDO ARMAS ASIN \\ ISET, Lima
}

\section{Resumen}

Estudio de las dificultades que encontraron los primeros jesuitas que fueron al Perú en las autoridades civiles, eclesiásticas e inquisitoriales.

\begin{abstract}
The first jesuits who came into Peru suffered continuous difficulties in front of civil and eclesiastical authorities and because of the inquisition.
\end{abstract}

El 28 de marzo de 1568 arribaron al Callao siete jesuitas, integrantes de la primera expedición enviada al Perú para fundar una Provincia de la Orden. La primera en Sudamérica. Antes, la expedición a Florida, les había servido como experiencia. El 1 de abril hacían su entrada en Lima en medio del gran regocijo general, y particularmente del Gobernador Lope García de Castro y del atzobispado Loayza. Diversos sectores del Virreinato peruano habían deseado durante años su venida como necesaria para ayudar a fortificar los frutos en estas tierras'. Habían traído al Perú la esperanza de un espíritu y comporta-

1 Ruben Vargas UGaRTE, Historia de la Compañía de Jesús en el Perí. Burgos 1963, t. l.,p. 23; Jacinto BARRASA Historia de la Compañia de Jesüs en el Perú Lima, p. 77; Anello Oliva Historia del reino y provincia del Perí Lima 1895 (1598) p. 156; Diego DE CORDOVA Y SALINAS Crónica franciscana del Perú (ed de Lino Canedo) Washington 1956., p. 500. 
miento nuevos, que debía llenar de gozo a los hombres más instruidos del virreinato alarmados por algunas lagunas existentes en la labor eclesiástica. «Lo espiritual ha estado y está muy caído en estos reynos, y así hecho poco provecho en la doctrina de los naturales: caúsalo los muchos malos ejemplos que en esta tierra se han dado y dan y el descuido de los Perlados» argumentaba el dominico Francisco de la Cruz, téblogo, profesor de San Marcos y doctrinero ${ }^{2}$. El mismo había pedido en todos sus votos una reforma, en la cual a sus ojos la Compañia de Jesús sería uno de los instrumentos más poderosos «Porque los religiosos de esta tierra, vivimos con poco ejercicio de devoción, por habernos dado tanto a las doctrinas, y porque hay poca mortificación cristiana en todos estados, sería muy gran remedio...que V.M. envíase acá teatinos» sentenciaba en esa carta de inicios de 1568. Como para responder al deseo, se realizó la Junta Magna, y antes de llegar Toledo y la Inquisición, arribaron los jesuitas a levantar el espíritu.

Pero ya el 1 de marzo de 1566 el Rey escribía en Cédula a Francisco de Borja en Roma para que escogiese elementos probos entre los suyos para mandarlos a Indias. En tal sentido Borja pasó a formar lo que sería la primera expedición que enviaría al Perú. En 1567, reunió un grupo de ocho religiosos tomados dos de cada una de las cuatro provincias jesuitas españolas: el P. Diego de Bracamonte y el H. Juan García, de Andalucia P. Miguel de Fuentes y el H. Pedro Pablo Llobet, de Aragón; los PP Jerónimo Ruiz del Portillo y Luis López, de Castilla; y de Toledo el P. Antonio Alvarez y el H. Francisco de Medina $^{3}$. Por ser el más antiguo y más destacado en cargos desempeñados, fue elegido Jerónimo Ruiz del Portillo como Provincial (rector de Simancas y Valladolid en Colegios de la orden, y viceprovincial de Castilla). Luis López era el segundo en importancia y el más docto en formación. Le seguía luego Bracamonte. Precisamente éste diría en 1569, desde Lima, al encargársele componer para el Superior General el catálogo con las primeras actividades de la Provincia recién fundada - la primera Carta Anual-, que López era un hombre de muchas letras y que siempre necesitaba estar muy ocupado, aunque le reconocía cierto genio difícil ${ }^{4}$.

2 Cf. Emilio Lisson, La Iglesia de España en el Perü Sevilla 1944, t. II (7) doc 338, pp 304308.

3 BARRASA, o.c., p. 68; VARGAS UGARTE, o.c., t. l., p. 11.

4 Monumenta Peruana t. l., doc 67, pp. 219 y ss. Habia nacido en Estepa, Andalucia, en 1536. Obtuvo los grados de Maestro en Artes y Bachiller en Teologia en la Universidad de Zaragoza, ingresando ya como sacerdote a la Compañía de Jesús en 1564, en Salamanca. Ibid., t. I p. 129 y T. II doc 117; J.T. MEDiNA, Historia del Tribunal del Santo Oficio de la Inquisición de Lima. Santiago, Imp. Gutemberg 1887, t.I, p 99; Francisco MATEOS (Ed), Historia General de la Compañía de Jesús en la Provincia del Perú. Madrid, CSIC 1944, p.11; Alvaro HUERGA, Historia de los Alumbrados, t. III; Paulino CASTAÑEDA y Pilar HERNÁNDEZ, La Inquisición de Lima. Madrid, Deimos 1989, t, I, p.308.

Proyección intemacional de la iglesia hispana Hispania Sacra 51 (1999) 
Tan pronto llegaron a Lima, se hospedaron en el convento del Rosario de los dominicos, en espera de la real orden que le señalase el lugar en donde debían edificar casa y capilla. Pronto lograron obtener el sitio apropiado, se acomodaron como pudieron y empezaron a ejercitar los ministerios de su orden. El Padre Portillo predicaba y resolvía los numerosos casos de conciencias, que abundaban en Lima. El P. Diego de Bracamonte, quien además era rector del Colegio, enseñaba catecismo a los niños españoles y a los indios. Numerosas vocaciones, muchas insignes, se presentaron. Quince entraron al Noviciado sólo en 1568, entre ellos el Licenciado Pedro Mejía, fiscal de la Audiencia; el secretario de la misma Francisco Lopez de Haro; el Dean de la Catedral, Juan Toscano; el canónigo del Cuzco, Cristóbal Sánchez; Martin Pizarro, joven mayorazgo., y algunos mestizos que los padres escogieron especialmente para la labor de catequesis. Entre los que se encontraba Blas Valera, que entró al Noviciado el 29 de noviembre de aquel 1568.

El P. Luis López, en el entretando, se ocupó en dar los ejercicios espirituales a los de su Orden, a españoles laicos, y además trabajó en la envangelización de negros:

\begin{abstract}
El Padre Luis López, fuera de las confesiones en Iglesia y la asistencia a los moribundos, ha tomado el cuidado de los negros, que son muchos en la ciudad. Reínense los domingos como unos 2000 en nuestra casa y el Padre con tres Hermanos los conduce por las calles hasta la catedral, cantando la doctrina y, en llegando al templo, se les enseria el catecismo por preguntas y respuestas y luego los hace una exhortacion acomodada a su capacidad. El fruto que se advierte de este ministerio es grande, pues han cesado los bailes y escandalos que daban y aún las muertes entre sí y ya no huyen al monte, cuando temen algún castigo de sus amos, sino que vienen a que el Padre interceda por ellos. Esta reforma en una clase tan abandonada no pudo menos que conmover a la ciudad y llenarle de admiracións.
\end{abstract}

Ejerce el ministerio espiritual. No ocupa cargo institucional de importancia. Está realizando (el único a quién Bracamonte se refiere en forma concreta y como ejemplo) labor pastoral. La experiencia con los negros de Lima le permite trabajar en la metodología que está afincándose en Perú: catequesis de domingos, preguntas y repuestas, sermones por las calles, etc. Una práctica que se trasluce ya (en términos integrales) desde el II Concilio de 1567, y que estará muy presente en la posterior práctica que impondrá el Tercer Concilio Limense a las normas del tratamiento a naturales. Acción no exclusiva sólo de jesuitas.

5 Primera Carta Annua, escrita por Baracamonte el 21 de enero de 1569, Monumenta t 1, doc 57 p. 253 y ss.

Proyección internacional de la iglesia híspana Hispania Sacra 51 (1999) 
En 1569 llegaba al Perú don Francisco de Toledo, juntamente con los futuros Inquisidores del Perú (Serván de Cerezuela y Gutiérrez de Ulloa) y también con la segunda expedición de jesuitas: el P. Bartolomé Hernández (que se desempeñaba como confesor del Virrey), el futuro gran misionero y linguista Alonso de Barzana, Rodríguez Alvarez, Juan de Zuñiga y otros. Era el 8 de noviembre ${ }^{6}$. El último de estos jesuitas, Juan de Zuñiga, sería quien en los Catalogi Trienales et breves (1568 - 71) compuesto cuando ejerció el rectorado del Colegio de Lima, años después, se refirirá a López exaltando su talento, aunque hallándolo «recio de condición y poco amoldado al tallo de la Compañia y es muy libre y poco aficionado a los casos de mortificación »? Comentatios hechos sin duda, cuando el nombre de López estaba complicado en asuntos delicados. Y cuando también le habían nacido celos profesionales con el hermano. $\mathrm{Y}$, sin embargo, hubo de resaltar el hecho de que era un hombre talentoso.

En efecto, lo era. Tanto en las tareas pastorales que se le encomendaban, como en su percepción de las cosas y acontecimientos que observaba alrededor. Así el 29 de diciembre de 1569 -siete semanas después del arribo de Toledo, la Inquisición, y la segunda expedición jesuita- escribe su primera carta al Padre General Francisco de Borja ${ }^{8}$. Hecha después de la Carta Anual alude a esta «por haber dado cuenta larga el Padre Provincial, de nuestro camino y suceso, y no haber entendido bien esta tierra, no e querido hacerlo hasta ahora que puedo en alguna manera decir algo de lo que e visto e calado. Y no diré de las cosas universales que por medio de la Compañia Nuestro Señor a hecho, pues de ellas V.P. tiene larga relación...»9. Y a continuación expresará sus impresiones del Perú, del estado de la labor misional, con un análisis agudo y crítico de la sociedad colonial. Apasionado, como ya lo reconocía Bracamonte, no tendrá inconvenientes en observar a la propia Compañía: «Y entre las cosas de que mayor necesidad hay es de un Maestro de noviciado...». Miguel de Fuentes era el Maestro en funciones.

La segunda y tercera cartas (escritas el 21 de enero y 2 de febrero de 1570) mantienen esta posición de juicio sobre el entorno social, agregando su disconformidad sobre el aceptar doctrinas de indígenas ${ }^{10}$. Como Bartolomé Hernández, era parte de un sector de la Orden no dispuesto a ceder a las presiones del Virrey, que cuestionaba sus especiales constituciones internas. Como sabemos, el asunto se resume en el hecho de que el Virrey decidió que ellos, pues era la función de las órdenes en América, se encargasen de doctrinas de indios. La

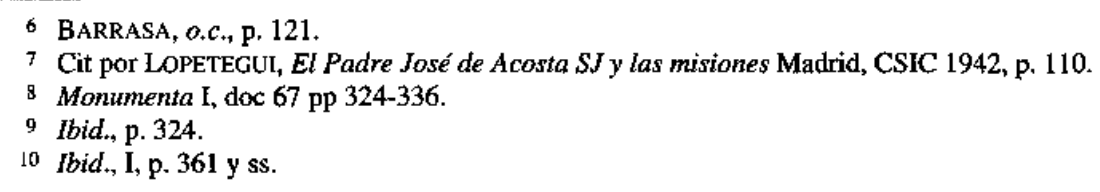

Proyección internacional de la iglesia hispana Hispania Sacra 51 (1999) 
Provincia Peruana respondió tener reparos en aceptarla bajo las mismas condiciones que otras. Al final se aceptaría, pero bajo ciertas restricciones. En 1569 se harán cargo de la doctrina de Huarochirí (que dejarán en 1573) y en 1570 la de Santiago del Cercado, para finalmente en 1576 coger la de Juli ${ }^{11}$. Desde 1570 , empero, las presiones de Toledo (que con los años no haran sino multiplicarse) apunta a que se hagan cargo de más doctrinas. Lo que provoca el rechazo que muestra López ante su Padre General. Y la alerta ante la pasividad de otros jesuitas frente a los arrebatos del Virrey. Talentoso y crítico se presenta en estas misivas. Demostrando no tener reparos en denunciar hechos y a personas. Como en ir formando un carácter y opinión contrarios al poder temporal y la sociedad de entonces.

1570 es el año de sus impresiones. En Lima. También es la fecha de su participación de unos exorcismos, sobre los que luego se tejerían muchas conjeturas que terminarían por enredarlo. A pesar de que empezó por ser un servicio al familiar de un hermano.

En efecto, había en la ciudad una joven criolla, llamada María Pizarro, hija de Catalina Cermeño y Martín Pizarro y hermana del novicio Martín Pizarro. Dicha joven sufría de extrañas alucinaciones y 'dolores de costado' que lentamente la estaban llevando a la muerte. Pero dado que sufría de alucinaciones cada vez más extrañas, se cayó en la cuenta, y ella fue la primera en afirmarlo, que se introducían demonios a su cuerpo que le provocaban noches turbulentas. Ante tales perspectivas y dada la relación de la familia con los jesuitas, se les pidió que intercediesen para buscar un remedio. Fue así como empezaron a reunirse en casa de María Pizarro (y con las respectivas licencias arzobispales) para exorcisarla en las noches. Eran el Provincial Portillo, Miguel de Fuentes y Luis López. Parece que esporádicamente otros jesuitas participaron en las sesiones. Como fuere Luis López se convirtió rápidamente en el exorcista principal $^{12}$. ¿Porque era el más docto y preparado?. Parece que las sesiones ayudaron a mantener en sosiego a María, dado que llegado un momento se interrumpieron. Luego López, acompañando a Portillo y al Virrey, partiría hacia el Cusco. No volvería a esa casa. Cuando poco después ella volvío a sus alucinaciones y problemas de demonios serían los dominicos $\rightarrow$ pedido de la fami-

11 VARGas UGARTE, o.c., p. 62; ARMAS MEDNA, Cristianización del Perú. Sevilla, EEH 1953; LISSON o.c., II-(8); Marie Helmer, «Juli, un experimento misionero en los Andes peruanos» en Bira 3 (1982-3).

12 Castañeda, o.c., t. I,p. 310 . Borja, al enterarse de esas actividades le escribiría a Portillo, no estar de acuerdo pues anosotros más pretendemos sacar los demonios de las almas que de los cuerpos, y no tener familiaridad con el devoto faemoneo sexu, aunque ellas tengan familiares [en la Compañía]». Sabía el General no solamente que «se ha gastado mucho tiempo y con poco fructo en los exorcismos» sino que además podría atraerles problemas futuros, pues a veces «donde se pretiende hazer obra de charidad, podría salír obra scandalosa, o al menos de mal sonido». A. EGAN̄A, «El Virrey Don Francisco de Toledo y los Jesuitas del Perú en: Cuaderno de Deusto IV/7(1956), p. 176. 
lia-los que acudirían en su ayuda. Entonces el asunto tomaría ribetes distintos, que terminarían envolviendo a los jesuitas.

\section{UN SACERDOTE VIAJERO: 1570 - 1575}

El 22 de Octubre de 1570 emprendía el Virrey Toledo la célebre Visita General del Perú, en dirección al Cusco. Se encontraba en su comitiva el Provincial de los jesuitas, Ruiz del Portillo asi como Luis López, y los hermanos Antonio Gonzáles de Ocampo y Gonzalo Ruiz. La comitiva se detuvo en Guamanga algunos dias, y esto aprovecharon los jesuitas para adelantárseles y llegar primeros al Cusco, con el fin de apresurar la fundación de Casa y Colegio de la Compañia. Ciertamente el viaje con Toledo fue aprovechado para poder expandir la labor misionera, aunque en el detalle del apresurarse en el viaje de Guamanga a Cusco Bataillon vea un índice por tratar de mostrarse independientes a los ojos de la sociedad y Vargas Ugarte lo vea como un mero hecho de fervor misionero ${ }^{13}$. Pareciera obvio que el excesivo favor toledano fuese un inconveniente a la Compañia, como bien puede notarse en los cambios de actitud de algunos dominicos y franciscanos. Luis López mismo, en carta del 21 de enero de 1570, había mostrado esa cierta desazón de las otras ordenes por el favor a los jesuitas en esos años iniciales.

El Virrey nos hace mucha merced y favor: pero no me consolara que ninguno de la Compañía le confesara (serían tres sus confesores privados, entre ellos Portillo y Bartolomé Hernández), asi por el bien universal de las almas como por la Compañia. Si en España se huye de confesar al Rey, con mayor razón en ésta tierra al Virrey. Porque de confesarle es imbidiada la Compañía de las demás ordenes, con las cuales conviene tener mucha unión, y todo cuanto hiciere el Virrey de bien, se ha de atribuir a él; y de mal, al confesor y a la Compañía, como a sucedido aquí al Comisario General de los Franciscanos con el Presidente Castro... ${ }^{14}$.

Sea como fuese, los jesuitas asentarían su labor en el Cusco, conviviendo con el Virrey en el tiempo que este estuvo allí. Fundaron un Colegio donde

13 M. BATALLON «La herejia de fray Francisco de la Cruz y la reaccion antilascasiana», Estudios sobre Bartolomé de las Casas. Madrid, Península 1972.. Portillo además era confesor del Virrey. El viaje despertó un cúmulo de sospechas sobre el creciente privilegio que recibían del gobiemo los jesuitas. Algo que el mismo Borja comprendería, al reprobar la manera cómo se mezclaban con el poder político. EGAÑA, o.c., pp. 136-137.

Por otro lado, la aseveración de Egaña, que Portillo se llevó consigo a López para alejarlo de Lima, es inverosímil. 1570 no es un año peligroso todavía para el sacerdote. No hay ni denuncias ni comentarios sobre su persona.

14 Monumenta, $1, \mathrm{p} 367$.

Proyeccion intemacional de la iglesia hispana Hispania Sacra 51 (1999) 
erigieron Cátedra de Lengua General, mandando traer a los padres linguistas Alonso Barzana, Blas Valera y Bartolomé de Santiago, para su dirección. De la misma manera el Provincial Portillo llamará de Lima a Diego de Bracamonte para que se haga cargo del rectorado de dicho centro. Objetivamente hablando el papel de López es bastante secundario en esos momentos.

Pero la partida de Portillo hacia Lima, en las antípodas de un nuevo enfrentamiento de los jesuitas con Toledo, hará que tome de pronto un rol primario. En efecto, dado que el asunto de negarse a recibir doctrinas estaba muy en la mente del Virrey, tratará de presionarlos ahora nuevamente. Dispuso en el Cusco que su confidente y partidario, Diego de Bracamonte, viajara a España y luego a Roma, a informar como Procurador extraoficial de los problemas graves que para la Provincia y la evangelización implicaban el no recibir doctrinas - resignado Portillo, luego, autorizó la partida- El 22 de febrero de 1572 salió a Arequipa, y el 20 de marzo se embarcó en Islay. A la larga su comisión no debio surtir mayor efecto, pues quedó en pie la resolución del Padre General sobre en qué circunstancias recibirlas ( 3 de octubre de 1568$)^{15}$. Lo pertinente es que, desde 1571, tuvo que hacerse cargo López de la rectoría del recién fundado Colegio, por la marcha de Bracamonte (hasta entonces era vice rector). Y porque Juan de Zuñiga, nombrado por Portillo para serlo, se hallaba en La Paz. López en verdad, tuvo que dedicarse a las tareas primarias del Colegio. Pues ni siquiera contaba con local. Estuvo casi dos años dedicado a consolidar la institución. En cuanto a Zuñiga, se hizo cargo del Colegio limeño después. Pero reaccionando contra su hermano en los términos que sabemos.

La presencia de Bracamonte en Roma, y sus circunstancias, provocará que el nuevo Prepósito General - Borja ha muerto-- Everardo Metcuriano, envíe un visitador al Perú, Juan de la Plaza, que llegará a Lima el 31 de mayo de 1575 , en compañía de un nuevo contingente jesuita (Juan de Montoya, Baltasar Piñas) y del mismo Bracamonte. Para Roma era imprescindible saber en qué estado se encontraba la Provincia. A los inconvenientes con Toledo por aquel viaje a Europa, se sumaba la carta que el P. Bartolomé Hernández había escrito a Juan de Ovando, Presidente del Consejo de indias el 19 de abril de 1572 , negándose a la idea de aceptar doctrinas ${ }^{16}$. El, como López, se mostraban disconformes. Pero, además de este tema, había otras situaciones que preocupaban al Prepósito General. Por ejemplo, las acusaciones que los propios miembros de la Provincia hacían sobre el Provincial. En tres cartas a San Francisco de Borja $\rightarrow$ sin saber de su muerte-López lo ataca ${ }^{17}$. Lo acusa de

15 MATEOS, o.c., p. 16.

I6 LISSON, o.c., II-(9) doc 413, pp. 598-609.

17 Es la afirmación de VARGAS Ugarte, o.c., 1, p. 56. Solo conocemos la existencía de una. Monumenta II, p. 489 y ss. 
prescindir en sus decisiones sobre la Provincia de la anuencia de los consultores. Y de guiarse tan sólo por los consejos de dos jovenes estudiantes recibidos en Lima. Esto último lo repitirá Juan Zúñiga, y después Acosta. El primero, el 31 de diciembre de 1572 , sugiere se envie un visitador «La provincia está en gran manera destruída», y acusa a Portillo de actos contra la castidad (¿los asuntos de María Pizarro de 1570, que por aquel año 1572 ya se han revelado en Lima?). También habla sobre los dos jóvenes, José de Rivera y ...Martín Pizarro. Acosta también escribe (influenciado por estas denuncias) el 18 de noviembre de 1572. Dice que hay descuido en la Provincia, trato con mujeres, falta de tacto con los estudiantes. Repite los argumentos de Zúniga y agrega relaciones del Provincial con dos mujeres, una de ellas hacía tres años - 1570-. Indudablemente el proceso inquisitorial contra María Pizarro, y sus terribles confesiones, envolvieron a Portillo. Ciertas o no, Acosta era Consultor del Santo Oficio, y por tanto tomaba nota de ello.

...así como lo sucedido durante su gobierno de provincial...como por la correspondencia de los sujetos de su tiempo, parece que le faltaba al P. Portilllo un tanto de severidad. Era a veces condescendiente en demasía y, por otra parte, le faltaba algunas veces resolución para adoptar el partido que aconsejaba la prudencia. Ya en el año 1575, en que llegó al Penú en calidad de Visitador el P. Juan de la Plaza, comenzaron a acumularse algunos cargos contra él y hasta el General llegaron las quejas ${ }^{18}$.

Asi pues llegó un Visitador. A la larga a Portillo no se le probó nada, y terminó sus días en diversas labores andinas de la Compañía.

Pero no solamente él tuvo inconvenientes. También López no pudo salvarse de denuncias en su contra. En una carta fechada en Roma el 28 de marzo de 1571, San Francisco de Borja le advierte al Provincial, que se encuentra con aquél en el Cusco:

...he entendido que el P. Luis Lopez ba enviado en nombre de una tercera persona mercader 200 ducados a dos hermanas suyas en España. Yo escribo al P. Cañas que se informe de si esto es así y empieza V.R. la información y nombres de personas de quien se sabe acá; y de quien se podrá saber en el Perú; y si la cosa es verdad y se ha hecho con noticia y licencia de V.R., déseme luego razón del negocio; y si no, embíese al dicho P. por orden mío a España sin decirle otra casa con la primera ocasión de pasaje; y en llegando a ella, el P. Cañas tiene orden mío de no recibirlo y tenerlo por despedido de la compañia... ${ }^{19}$.

\footnotetext{
18 VARGar UGARTE, o.c., t 1 p. 50.
}

19 Monumenta I, doc 88, pp 437-438.

Proyección internacional de la iglesia hispana Hispania Sacra 51 (1999) 
Obviamente se refiere a sucesos acaecidos en Lima, en 1570 o antes. El tema era grave, pues estaba prohibido entre los regulares, y más aún entre jesuitas, que se dedicaran a negociados y traslados de dinero. Aunque, al no volverse a hablar del caso parece que, o fue algo no probado, o se trató de un traslado de dinero institucional a España, como bien lo sugiere el mismo Borja. Everardo Mercuriano, le escribe a Lopez el 19 de noviembre de 1576 aludiendo indirectamete al asunto:

y entiendo que lo pasado habrá servido para prevenir a lo que podría acontecer adelante; y haya dado a V.R. ocasión de exercitarse quedando más aclarada su verdad y fidelidad con que ha exercitado nuestros ministerios, y espero que así será por delante ${ }^{20}$.

Tal vez tratando de aligerar las denuncias de 1571 , como obligado por su condición de Rector del Colegio, el 12 de octubre de 1572 escribe al General desde el Cusco $^{21}$. Habla de lo difícil del trábajo en tierras tan apartadas. Pero igual lo hace, misionando tanto con naturales como españoles. Lo que ha provocado que haya en el Colegio buena cantidad de estudiantes en la clase de gramática. Y aunque ya el Virrey en ese momento ha dejado la ciudad siguiendo con la Visita General, dá a notar el enorme apoyo que les ha dispensado. Aunque han tratado de mantenerlo apartado pues «él es el más aborrecido hombre del mundo, y todos los que tratan con él»22. A continuación expresa que «Lo temporal anda trabajoso, porque el P. Provincial tomó este colegio con confianza del Virrey, y él se a salido afuera, y déxome cargado de doce mil y quinientos pesos de deuda, y por hacer la casa, que serán más de diez y seis mil ducados, ay gran trabajo y más ahora quel Virrey me executó en cuatro mil ducados, Ios cuales con harto trabajo le a pagado... Todo este colegio y lo pedimos a V:P: por amor del Señor nos consuela con otra imagen como la de Lima, con cuentas agnus Dei y otras reliquias para este colegio... $\rangle^{23}$. La carta aunque estrictamente informativa, deja traslucir a primera vista una labor sacrificada pero que avanza, en medio aún de los imponderables del momento. Sin embargo el Provincial Portillo, de regreso de un viaje por Trujillo en 1573, nombra Visitador del Cusco a José de Acosta, pues parecía que no se hubierá entablado convenientemente la vida religiosa. Acosta llegó a mediados del 73 y parece realizó una labor ejemplar pues Portillo en la Carta Anual de 1574

\footnotetext{
20 Ibid., 1, doc 8 pp. 32-33.

21 Ibid., II, doc 103 pp. $489-449$.

22 Ibid., p. 491. De hecho, parece tuvo problemas con Toledo en el Cusco. Nuevamente por las doctrinas. Quería el gobernante que se asentaran en zonas indígenas, y ellos levantaron Colegio en el centro de la ciudad. EGAN̄A, o.c., p. 151.

23 Monumenta II, doc. 103, pp 492-493.
} 
dirá que la visita «se hizo con grande edificación y consuelo de todos y en lo espiritual y temporal quedó aquel Colegio mejorado». ¿Qué habiá ocurrido con el Colegio?. Es el Visitador Juan de la Plaza, en una de sus primeras cartainformes a poco de llegar al Perí, escrita en el Cusco el 12 de diciembre de 1576, quien expresa los detalles.

\footnotetext{
Al principio se pusieron dos clases de Gramática...el fruto no ha sido mucho en los estudiantes,por su remisión y por no haber sido los maestros bastantes...en este Colegio en los 2 primeros años no se guardaba regla general ni común, ni de oficio de rector ni de otros oficios particulares...En el modo de proceder dentro de la casa, en los dos años primeros, no se pusieron en exequción nuestras constituciones y reglas, por la ocupación del edificio material, y por atender a otras ocupaciones fuera de casa; pero de tres años a esta parte se ha puesto particular cuidado en esto, después que el P. Joseph de Acosta visitó este colegio por orden del P. Portillo, que entonces era Provincial; y así se ha guardado muy bien la observancia regular, y se executan todas nuestras constituciones y reglas enteramente... ${ }^{24}$
}

El visitador es claro en decir las causas que merecieron la visita de Acosta, aunque atestigua que tal vez era debido al cuidado "por la ocupación del edificio material, y por atender a otras ocupaciones», es decir por las labores propias de los primeros momentos de asentamientos: conseguir casa, atender espiritualmente a los españoles del Cusco,etc. La actitud imparcial y observante de Plaza le reconoce a López incluso los avatares que enfrentó al frente del Colegio: «Al principio entró la Compañia en esta ciudad con poco aceptación, porque entraron los Padres en compañia del virrey, y mostrávanse parte en sus negocios; después que el P. Portillo se volvió a Lima, apartándose del Virrey, fue la Compañia recibiéndose con más aceptación y acudían muchos a nuestra iglesia a confesar y comulgar...» Lo que en suma supone un reconocimiento a la obra de López.

Habiendo dejado el rectorado en 1573, el hombre que hasta este momento se nos presenta es ciertamente muy particular en comparación a otros jesuitas. Incansable defensor de la autonomía institucional, su actitud de desapego hacia Toledo y Portillo, bien puede notarse, asi como sus problemas limeños y en el rectorado cusqueño. Y a ello habría que agregar otras cuestiones en las que se vió comprometido, como la denuncia de que años más tarde sería objeto en el Santo Oficio, de haber tenido en el Cusco un altercado con un pároco por la interpretación acerca del significado del sacramento del matrimonio, que a sus ojos bastaba con ser válido si frente al celebrante la pareja asi como los testi-

24 Ibid., III, pp. 144-145.

Proyección internacional de la iglesia hispana Hispania Sacra 51 (J999) 
gos estaban conformes sin estarlo el cura. De hecho en el Cusco ordenó un matrimonio sin el consentimiento del celebrante ${ }^{25}$.

Cuestiones como ese hecho, que reconocería López después, más allá de probar o no su actitud de formalismos canónicos, demuestra más bien una posición por las soluciones practicas, como bien hasta este momento prueban sus diversas actitudes. ¿Cómo entender entonces al jesuita? De hecho es plausible admitir un ánimo por las soluciones unilaterales en él, siempre belicosas. Que las diversas denuncias en su contra llaman la atención. Sin embargo no podemos dejar de mencionar el gran cuidado en defender las cosas de la Compañía frente al poder temporal y el cierto sentimiento de respeto que despierta en personas como Acosta o el Visitador Plaza. De hecho, terminada la Visita de Acosta al Cusco en 1573, será López quien lo acompañe en una visita al surandino entre 1573 y 1575 , buscando lugares propicios donde asentar la labor de la Compañ́a.

Salen así del Cusco, con el Hermano Gonzalo Ruiz, y pasan a Arequipa. López se muestra como siempre solícito y entusiasta. Los sucesos pasados, como hubiera dicho Mercuriano, le habían dado ocasion para 'exercitarse'. Luego de estar en Arequipa, indagando sobre la posiblidad de asentar Casa, pasan a La Paz (ciudad incoada que no contaba con un asentamiento sólido y legal que se requiría para tener residencia y colegio). Se quedaron para la cuaresma del 73. Llamados por Toledo, que se hallaba en La Plata, se trasladan a aquel sitio. Y de allí finalmente a Potosí, en donde se les unieron Gonzalo Ruiz y Alonso de Barzana. A fines de 1574 llamado por Portillo, Acosta regresa a Lima. Y al parecer López también. En 1575 estan en la capital por segunda vez.

\section{UN SACERDOTE VIAJERO 1576 - 1578}

En 1575 los jesuitas eran 60: 43 en Lima, 14 en el Cusco y tres en al residencia de la Paz ${ }^{26}$. Hemos dicho que el 31 de mayo de 1575 llegaba el Visitador Plaza al Perú. Larga sería su visita, pues duró hasta junio de 1579, en que partió con idéntico cargo hacia Nueva España. Uno de sus primeros actos al llegar fue el de nombrar Provincial al P. José de Acosta en sustitución de Jerónimo Ruiz del Portillo, el 1 de enero de 1576. Acosta así, asistido por Plaza, convocó a la Primera Congregación Provincial, que tuvo dos etapas: la de Lima entre el 16 y 17 de enero, y la del Cusco del 8 al 16 de octubre de 1576. Concurrieron a ella los hombres más insignes de la Compañia: Plaza, Acosta, Ruiz de Montoya, Portillo, Barzana, Bracamonte, Zúñiga, Luis López, Andrés

25 CASTAÑEDA Y HERNÁNDEZ, o.c., p. 310. Era una actitud canónicamente sostenible.

26 LOPETEGUI, o.c., p 110; MATEOS, o.c., p. 10. 
López, B. Piñas, Bartolomé Hernández, etc. Fue nombrado secretario de las sesiones el P. Luis López, y trataron todos los problemas que aquejaban a la Provincia. Así doctrinas como disciplina interna. Las actas fueron enviadas a Roma con el Procurador designado, P. Baltasar Piñas. Fue precisamente en esa Congregación que se rechazó nuevamente aceptar doctrinas sin tener en cuenta las intrucciones de P. General en 1568. Se aceptó la de Juli, empero, para no enemistarse con el Virrey ${ }^{27}$.

Como la segunda sesión de la Congregación sería en el Cusco, aprovechó Plaza para partir hacia allá, el 16 de mayo, iniciando su visita al interior de la Provincia. Le acompañaba Luis López, nombrado además su secretario personal. Se ha especulado que fue para sacarlo de Lima, puesto que en ese año de 1576 los procesos a los involucrados dominicos, en el asunto de María Pizarro, estaban en su climax ${ }^{28}$. Parece no ser tan cierto, pues la mayoría de procesados dominicos -excepto Cruz-, y la misma María, han muerto para entonces. Verdad es que las aseveraciones discordantes entre sí de los declarantes, comprometen a los jesuitas, y particularmente a López; y que muchos de esos elementos serviran para condenar a Cruz, el último sobreviviente. Pero si nos atenemos a la letra de lo ejecutado por el Tribunal limeño, a López se le pidió por escrito un testimonio de descargo. El cual hizo poco antes de salir de viaje. De modo que cumplió con lo pedido y el Tribunal no lo molestó.

Llegó al Cusco el 11 de junio y asistió a la Segunda sesión de la Congregación Provincial. Se quedó hasta el 14 de enero de 1577, cuando Plaza decidió salir a Potosi para favorecer la apertura del Colegio recién instalado. Llegaron el 17 de febrero, permaneciendo hasta el 4 de setiembre, debido a que en el interregno, estallaron nuevos problemas con el Virrey.

El 6 de enero del 77 se había abierto el Colegio, pero el 6 de julio don Francisco de Toledo ordenaba que no se siguiera adelante en la fundación pues le faltaba la respectiva autorización real, en virtud de los derechos del Real Patronazgo a controlar el asentamiento de religiosos. Autorización que en el Virreinato solo le correspondía dar a él, en su calidad de Vice Patron. Ante lo delicado de la situación, llegaron Plaza y López, para ayudar a los hermanos, que aduciendo tener bulas especiales, se negaban a acatar la ordenanza. Toledo volvió a repetir el 12 de agosto la medida, aunque esta vez pidiendo que se retiren al Cusco, pues cerraría el Colegio. La provisión estaba dirigida a Plaza,

27 ARMAS MEDINA, O.c., p 171; MATEOS, o.c., p. 17; TORRES SALDAMANDO, o.c., p. 59.

$28 \mathrm{Cf}$ al respecto Pedro Borges, Métodos misionales en la Evangelización de América. Madrid CSIC 1980. Curiosa suposición, pues en ese año obtiene la profesión de cuatro votos, reservada a los miembros más insignes de la Orden. Aunque Borja nunca estuvo muy conforme con ello, basicamente por «cartas que acá escrive, donde muestra estar poco quieto en esas partes». EGAÑA, o.c., p. 180. El diplomático Padre General veía en sus reflexiones potenciales enfrentamientos con la autoridad colonial.

Proyección internacional de la iglesia hispana Hispania Sacra 51 (1999) 
en su calidad de Visitador. Hubo él de hacer gala de dotes diplomáticas, pues hasta el 4 de noviembre en que permanció con López en Potosí, intentó un acuerdo de compromiso. Y parece que lo logró, pues la orden quedó sin cumplirse. Aunque paralelamente los trabajos de construcción del Colegio quedaron truncos. El 27 de noviembre arribaron a Juli, creyendo momentáneamente superado el problema.

Fue una experiencia terrible, particularmente para López. En quien sin dudas se fortaleció la opinión negativa sobre el Virrey, «el más aborrecible hombre del mundo». Como también en otros miembros de la Compañía, y en el mismo visitador Plaza. Con estos recuerdos, se dedican a inspeccionar la doctrina de Juli, la nueva obra que realizan los jesuitas, y que más tarde se convertiría en un centro de irradiación misionera y modelo evangelizador en los Andes. Parece que permanecieron hasta el 15 de diciembre de 1577. Escasas semanas, pues Plaza desea impulsar el trabajo que Acosta y López tentaron en Arequipa en 1573. La expansión de la Compañía en el surandino le interesa de sobremanera. Por lo que se desplaza al lugar con López, llegando el 12 de enero de 1578.

Permanecieron muy poco tiempo, pues luego regresaron al Cusco, donde Plaza debió atender problemas administrativos derivados del Colegio cusqueño. Sin embargo la breve estancia no quedó sin consecuencias. Pronto el rico encomendero Diego Hernández Hidalgo, antes de morir, les dejaba una fuerte dotación de dinero a cambio de que fundaran Casa y Colegio en Arequipa. Pero como las claúsulas del testamento eran claras en dar un tiempo determinado para acogerse a la donación,

\footnotetext{
«...avisaron de todo de parte de la dicha ciudad al Padre Doctor Plaza Visitador de la dicha Compañía a la dicha ciudad para tomar la posesión y dar traza en la obra por que se pasaba el termino señalado por el dicho Diego Hernandez difunto y visto por el dicho Padre Visitador la instancia de la ciudad y particulares y la necesidad que ay de doctrina en aquella tierra para los españoles y naturales aceptó la dicha manda y fundación y por que se pasaba el termino y avia peligro en la tardanza envió a dicha ciudad de Arequipa dos religiosos de la dicha Compañía para tomar posesión de los quales fueron a la dicha ciudad y compraron una casa en la qual hicieron un altar y oratorio...29
}

Quienes fueron a Arequipa a instalar la casa eran los hermanos Antonio López y Marco Antonio. El 14 de agosto. Pero nuevamente no piden las licencias al Virrey. La premura por no perder la donación sin duda ha motivado la ligereza. Corno también el considerar que no la necesitan «en virtud de las bulas apostólicas» que confiere a la Compañía potestad de fundar casa y Colegio donde mejor le parezca. Según la opinión que tienen. Plaza de todas mane-

29 LISSON, o.c., II-9 doc 497, p. 4. 
ras sabe cual será la reacción del Virrey, por lo que envía de prisa a Arequipa a Luis López y Alonso de Barzana. El primero como Superior de la casa. Y hace regresar a los dos hermanos.

Hay dos puntos que es bueno entender hasta el momento. La ligereza de no pedir licencias puede ser visto en perspectiva meramente formal amparado por el natural cuestionamiento de la Compañía a aceptar pasivamente los puntos límites del regalismo toledano. Lo cual nos lleva a entender las características internas de la Orden frente al tema general del Patronato. Aunque también podamos intuir una cierta predisposición de la Compañía -recuerdese que de Plaza y Lopez dependen practicamente las acciones de los jesuitas en el surandino--, luego de lo sucedido en Potosí, a propiciar un nuevo enfrentamiento. Lo cual nos llevaría al segundo punto. López se queda al frente del Colegio de Arequipa. El hombre que más ha criticado a Toledo. Plaza no sólo razona en terminos de tratarse de su secretario personal, y por tanto resulta algo obvio que le encargue tal misión, sino de ser, sin ambages, quien mejor conoce las iras de don Francisco. Acaso en esa responsabilidad, como en la premura del asentamiento de Arequipa, podamos detectar a un Visitador fuertemente influenciado por López. ¿Que lo lleva a sucesivos enfrentamientos? Al fin y al cabo, la orden para el asentamiento de Arequipa dependió de Plaza, «el dicho Padre Visitador embio los dichos dos religiosos a la dicha ciudad».

Es importante la atingencia. Si bien hemos aludido en forma rápida los viajes que realizan juntos, no hemos utilizado una profundidad metodológica para entender el grado de relación que tienen. Tal vez el mismo hecho de ser secretario personal el uno y visitador el otro puede ser un indicador de la amistad, o tal vez la carta-informe anteriormente revisada sobre el Colegio del Cusco en sus primeros años. En donde Plaza defiende hasta el límite a López, y habla largamente de su persona y cualidades (extraño en un informe) o quizá otros elementos como aquel que a instancias de Plaza, escribe López un cuaderno de notas, con cuestiones relativas al estado del virreinato, criticando al Virrey y defendiendo a la Compañía y su posición sobre doctrinas, asentamientos de casas, etc, con la intención de los dos de ir en algún momento a Madrid y Roma a quejarse de lo sucedido. Justamente en esos momentos aciagos, mientras viajan por el sur. $\mathrm{O}$ tal vez las cartas que escribe a Everardo Mercuriano para que Plaza no se vaya del Perú, que obligan al Propósito General a decirle que «Harto me consolará y también de que el P. Plaza se quede hay como V.R. me lo escribe más ha sido necesario su ida a México para hacer, en aquella Provincia lo que ha hecho en esas...» ${ }^{30}$. Cuando Plaza esté por partir a México en 1579, tratará de llevarlo consigo.

30 Monumenta II, do 88 pp. 437-438. 
López se queda en Arequipa entonces. Y escenificará el más sonado enfrentamiento de la Compañía contra el poder virreinal en el Perú. Ya el 14 de agosto mismo, a poco de llegar los hermanos y fundar el Colegio las autoridades de la ciudad les pidieron que abandonaran el lugar pues se había hecho «yndebidamente en gran desacato de la magestad del Rey», pues había «provision rreal de su Magestad e de su Excelencia para no fundar monesterio ni colegio ...sin expresa licencia». Lo que se negaron a hacer.

A lo cual las autoridades cumplieron con hacer del conocimiento de Toledo lo sucedido. El 9 de setiembre, furibundo, el Virrey emite una ordenanza, en cumplimiento de las «provisiones y cedulas de su magestad para la conservación de su patronazgo Real», por medio del cual ordena que a los dos hermanos «los saquen de la dicha ciudad como lo debiera el dicho corregidor aver hecho y los embarque para esta ciudad y todos los bienes temporales y casas que tuvieren en la dicha ciudad de arequipa las cierre y embargue» ${ }^{31}$. Pero ya Plaza los ha reemplazado por López, Barzana, y un hermano llamado Casasola.

A ellos el 27 de Octubre se dirigen las autoridades, para que «Yncontinenti salgan de la casa que tienen poblada...so pena de las penas puestas por las cedulas de su magestad». López, como Superior responde al auto de apercibimiento: desea contestarlo «dentro del término que el derecho canónico y civil les da». A lo que responden las autoridades, que solo cumplen ordenes y por tanto no es posible la dilación. Todavía el jesuita se resiste, arguyendo que «por obediencia de su visitador y provincial» no «pueden salir sin yncurrir en appostasia», por lo que pide se les notifique para que ellos le ordenen hacer$10^{32}$. Ante la nueva negativa, todavía insiste en negarse a abandonar el lugar «por obediencia a dios y a sus superiores...y por virtud de las bulas apostólicas». A lo cual las autoridades tuvieron que pedir la intersección de «alcaldes y regidores vexinos y particulares desta ciudad que presente estavan e al señor vicario don martin abad de usonsolo e a los demas clerigos y personas eclesiásticas que presenten estan den favor e ayuda para los echar de la dicha casa».

Finalmente logran sacarlos. No sin las protestas de Luis López que pide al escribano tome nota de la violencia:

dixo que pedia se le diese por testimonio como los señores juezes los sacaban de sus casas lo qual dixo...estando ya fuera de las dichas casas....e queriendo dezir y alegar otras cosas el señor don Juan y corregidor dixeron que ya avian hecho el cumplimiento de la dicha provision de su excelencia, que buscase escrivano e que no se escriviese otra cosa....

31 Lisson, o.c., I-9, doc 477 , pp. 475-479.

32 Ibid., II-9 doc 478 ., p. 480.

33 Ibid., p. 481. 
Asi termina el episodio. Aunque el Virrey no logra apresar a Antonio López y Marco Antonio, que «cinco o seis dias que se avian ydo desta ciudad».

Luis López regresará a Lima en noviembre de 1578, siendo ya una figura incómoda para Toledo, que está perfectamente enterado de los pormenores de lo acontecido. Plaza por su parte, también a regresado del Cusco en octubre. El último acto iba a empezar.

\section{EL INICIO DE LAS TRIBULACIONES}

En Lima, en octubre de 1578, también ocurrió otro hecho que contribuyó a reforzar una suerte de tensión en las relaciones de Toledo con la Compañia, ya muy agravadas de por sí. Fue el cierre del Colegio en Lima. En efecto, esta vez el enfrentamiento se dió debido a que el Virrey, luego de haber laicizado la Universidad de San Marcos por orden de Felipe II (antes estuvo en manos de dominicos), tuvo en consideración que el Colegio Jesuita de San Pablo competía con la Universidad, hasta el punto de ser preferida por los estudiantes. Lo cual no sólo contradecía la política educativa regia, sino que implicaba una peligrosa influencia, que deseaba evitar. Por lo cual invitó desde 1576 a los profesores de San Pablo a dictar en San Marcos. Era obvio, por la labor que realizaban en el Colegio, concebido como pastoral educativa, que no iban a aceptar. Y efectivamente, asi sucedió, pasando dos años. Hasta que curiosamente en ese mes de octubre actuó el Virrey. Ante una petición formal del claustro de profesores sanmarquinos, el 10 ordenaba cerrar el recinto jesuita, aduciendo competencia desleal con la Universidad ${ }^{34}$. Hoy se sabe que los profesores eran amigos del Virrey y actuaron a solicitud suya. El clima a esas alturas era delicado, a pesar de la acción desplegada por José de Acosta, Provincial y Consultor del Santo Oficio, que trataba de limar asperezas. Y como para complicar más el panorama, tres dias antes, el 7 de Octubre don Francisco firmaba una ordenanza para que se cerrara de una vez el Colegio de la Compañía en Potosí, cuya situación todavia estaba irresoluta. Para el Virrey, el nombre de la Compañía le debió de sonar a absoluta insumisión en esos días. «.tanto atrevimiento y avilantés». La orden no se cumplió hasta el $10 \mathrm{de}$ diciembre, en presencia del Provincial Acosta, que tuvo que viajar urgente al sur para detener la violencia. Y porque el toledano Portillo, superior de aquella casa, había abandonado su puesto, dejando a los suyos sin guía. Sin duda presionado por el gobernante. La acción del Virrey es envolvente entonces. Y uno tras otro van cayendo los bastiones jesuitas. En ese contexto de desaveniencia

34 EGAN̈A, o.c., pp. 168-171; VARGAS UGARTE, o.c., t. 1., cap IX.

Proyección internacional de la iglesia hispana Hispania Sacra 51 (1999) 
ocurrió otro hecho importante. Rápidamente por él capitalizado. Que le permitía de paso arreglar cuentas con el jesuita más «atrevido y lenguaraz».

El 1 de abril tenía lugar la ejecución, por parte de la autoridad secular, de la sentencia que diera la Inquisición el 14 de julio de 1576 contra fray Francisco de la Cruz, OP. En el imponente auto de fe que duró todo el día, los poderes temporales y espirituales se reunieron, para contemplar cómo sucumbía en la hoguera el fraile. Había sido el acto final de una historia que desde 1572 cautivó a los limeños. Historia de frailes predestinados y de una mujer visionaria, que había sobresaltado a la autoridad colonial, de por si atenta a cualquier brote de heteroxia. Todo se había iniciado en la casa de María Pizarro, aquella joven que sufría de desmayos - hoy sabemos que era epiléptica-y decía que veía al demonio en forma de Armado, que la atormentaba y no dejaba que tuviera noches tranquilas. Precisamente, Portillo, Lopez y Fuentes, en 1570 la habían exorcisado, tratando de ahuyentar al Armado. Pero, tras la partida hacia el Cusco, fueron los dominicos los que continuaron con las sesiones, a petición de la familia. Entonces Alonso de Gasco, Pedro de Toro (ex provincial) y fray Francisco de la Cruz, le dieron otro rumbo a los acontecimientos. Terminaron creyendo a pie juntillas lo que aseveraba María en sus visiones. Y el demonio fue reemplazado por un Armador bueno (San Gabriel) que les comunicaba profecias. Y creyeron en la nueva de la regeneración del cristianismo en el Nuevo Mundo, de un Papa nuevo. En que ellos serían los impulsores de la novísima Iglesia en Indias. La heterodoxia cundió en el grupo. Sin embargo hacia 1572 Toro partió como prior a Chuquisaca, Gasco a Quito como superior de convento, y el maestro Cruz se refugió en sus labores docentes de San Marcos. Parecía que el grupo había fenecido. Y lo hubiera sido, sino fuese por el sentimiento de culpa de Gasco, que terminó delatándose al obispo de su orden en Quito, Pedro de la Peña, que hizo que se presentara al Santo Oficio. Así los comprometidos fueron llamados a declarar. También María Pizarro. Dijeron más de la cuenta, particularmente ella, que agregó y desagregó hechos a sus testimonios. Lo entremezclaron todo. De modo que orientaron sus destinos por cuenta propia. Los procesos empezaron en 1571 y terminaron en 1576. En el camino murieron Pizarro y Toro (sin ser sentenciados en vida); Gasco sufrió pena a pesar de ser el delator; y finalmente Cruz, condenado a la hoguera ${ }^{35}$. ¿Por qué él sufrió el escarnio extremo? Porque no se retractó de las afirmaciones sobre la Nueva Iglesia, el Angel Bueno que hablaba por boca de María, etc. Terminó muriendo por heresiarca. Actualmente conocemos que en su proceso, como en el resto de acciones a los dominicos no solo estuvo la mano inquisidora velando por la ortodoxia doctrinal, sino que además las autoridades

35 Cf Abril Castello, «Francisco de la Cruz, la utopía lascasista y la contranreforma virreinalinquisitorial» Chela 3 (1980); HuERGA, o.c. 
coloniales, Toledo, los inquisidores mismos, utilizaron los hechos para desahacerse de los últimos resabios del lascasianismo en el Perú, de otras maneras de entender la sociedad colonial, las relaciones de poderes, las críticas a los nuevos vientos políticos en América. Los dominicos lascasianos, como los jesuitas, también tienen una historia de enfrentamientos con la autoridad toledana. Pero a diferencia de ellos, llegaron hasta el martirio.

Era el 1 de abril de 1578 y moría Cruz. Todavía López está en Arequipa. ¿Por qué es importante el acontecimiento? Porque a lo largo de los años que han durado los diversos procesos, los jesuitas han sido nombrados reiteradamente. Habían sido los primeros exorcistas. María, en sus enredadas declaraciones incluso llegó a sugerir faltas éticas y doctrinales en Portillo y López. Aunque después se retractó. Los dominicos, particularmente Toro, en su afán de salvarse trataron de afirmar las iniciales declaraciones de María Pizarro. Tal vez para despejar dudas, cuando ya solo quedaba por solucionar el caso de Cruz, el Tribunal aprovechó la estancia en Lima de López, y le pidió por escrito su testimonio. Como sabemos lo hizo.

Pero los problemas en Potosí, las noticias que de Europa llegaban sobre la supuesta presencia de jesuitas en los sonados procesos a «alumbrados» en Llerena, y el escándalo en Arequipa vuelve sobre ellos la mirada. Con nombres propios. Particularmente López. En todo el asunto de María y los dominicos además, Toledo no solo ha visto una conspiración de gente peruana contra el Rey. Dominicos lascasianos y distinguidos representantes eclesiásticos de la pasada década, participantes en el Segundo Concilio. Sino además de otras personalidades que compartían con ellos su común crítica al régimen. De hecho hablará de conspiración en 1572 , cuando los procesos a los dominicos empiecen. Para él no era casualidad que en aquel momento Toro esté en el Alto Perú, López en Cusco, Fuentes y Cruz en Lima, y Gasco en Quito. Es decir en todo el Perú. Era una «Suprema Conspiración de Yndias». La atención del virrey sobre López tenía entonces larga historia. Y ahora los acontecimientos de Arequipa. La irritación del Vice Patron debió estar, al regreso del jesuita a Lima (noviembre), en su cénit. No era para menos. Si tenemos en cuenta sus cartas de 1560-1572 al general Borja, su visión del asunto de doctrinas, y sobre todo algo que Toledo todavía no sabía: el cuaderno de notas que había escrito a instancias de Plaza. Cuando la Inquisición secuestró sus pertenecias encontró el escrito. Como una carta fechada en Roma (supuestamente) dirigida al Dr. Barros, oidor de Chuquisaca, donde argumenta que venía gobierno nuevo para reemplazar al Virrey. Barros también era un crítico de Toledo. Serván de Cerezuela, de la villa de Oropesa como Toledo e Inquisidor, le enviará todos estos papeles y él se los devolverá con una carta a Felipe II, donde trasluce todo su cólera contenida: «V.V mandará ver la libertad con que algu-

Proyección internacional de la iglesia hispana Hispania Sacra 51 (1999) 
nos destos tratan las cosas de vuestro real servicio y la ambición y sobervia de que siempre me pareció tener alguna parte este clérigo, con que quería meter la mano y tratar de vuestros reales derechos». El proceso que le iniciaba la Inquisición debió ser como tener la sartén por el mango, tener al sacerdote donde lo quería, y de paso a la Compañía en aprietos, a esa Compañía que a su decir hacía poco se les había ido la mano «en el extenderse y fundar muchas casas».

En noviembre de 1578 volvía López. Volvía respetado por los suyos. Pero exactamente ese mismo mes era detenido por el Tribunal del Santo Oficio de la Inquisición de Lima. ¿Bajo qué razones?

\section{II}

«...por muchas libertades y cosas que había dicho...», decían los inquisidores en carta a la Suprema y General Inquisición de Madrid en $1579^{36}$, sustentando por qué habia sido detenido.

$\mathrm{El}$ auto de Cruz despertó toda suerte de comentarios ${ }^{37}$. Luis López fue uno de aquéllos que se atrevio, hombre tan audaz, a opinar sobre lo sucedido. A su parecer, los inquisidores le habían hecho un enorme favor a Cruz, pues lo habian sentenciado por ser un heresiarca, cuando en verdad era un pobre loco, habiéndolo elevado de categoría. Agregando: «no quisiera tener yo conciencia de Cerezuela», refiriéndose expresamente al inquisidor Serván de Cerezuela.

Evidentemente no solamente ponía en tela de juicio la solvencia del Santo Oficio para juzgar casos como estos, sino que además era una burla y un ataque personal contra uno de los inquisidores. El Tribunal había tomado nota de lo ocurrido. Era una falta grave contra ella -un delito penado-. Había cometido una imprudencia evidente López, y el Santo Oficio decidió intervenir. Curiosamente en noviembre de 1578, en medio de las fricciones de Toledo contra los jesuitas. Secuestró todos sus bienes personales, asi papeles como enseres materiales, y lo puso bajo arresto preventivo en su Casa, para iniciar la fase informativa, vale decir la recolección de testimonios y análisis de escritos. A cargo del fiscal. Para poder elaborar las proposiciones de acusación y entrar al proceso en forma.

¿En qué circunstancias ocurrieron las palabras que se adjudican al jesuita, y que permitieron el arresto? Ciertamente, no hay evidencias al respecto. Debie-

36 Relación del proceso contra Luis López, AHN Inq Lib 1027 ff $118 \mathrm{v}-128 \mathrm{v}$,

El material del proceso se perdió, tanto en Madrid como Lina. De modo que hay que trabajar en los informes que el tribunal limeño enviaba periódicamente a Madrid. Sobre el estado de los casos en curso.

37 CASTANEDA, o.c., 309. 
ron de ser públicas para que llegaran a oidos del Tribunal. Pero lo que sí sabemos es que la Inquisición actuó con la tramitación convencional con que solía actuar frente a casos como estos de «palabras graves contra el Santo Oficio». Referirán los inquisidores que lo apresaron «...por muchas libertades y cosas que había dicho en el Cusco y en otras partes». Agregando, la multitud de sucesos que se han referido para los años anteriores a 1579 en la vida de López. Su posición frente a la Bula de la Cena, su visión del matrimonio y las ideas expuestas en las cartas. Que van saliendo a la luz conforme el fiscal va indagando y los testimonios apareciendo. ¿Sabía el virrey con anterioridad de todo esto? De hecho la Inquisición se sorprendería ante lo hallado y Toledo, en medio del enfrentamiento, también.

Lo que si tenía el Tribunal en sus archivos sobre López, era su participación en los exorcismos de María Pizarro ocurridos hacia 1569-1570. Sucesos por los cuales precisamente había muerto Cruz.

\section{UN PROCESO COMPLEJO}

Parece, por la ynformación que contra él avía antes en este Sancto Officio, que en los conjuros que se hicieron a doña María Pizarro fue el principal exorcista y el primero que trata de que se le aparecía a la dicha doña María aquel armado y el que comenzó a decir y publicar que era el angel de su guarda y que por lo aquel armado dezia por boca de la dicha doña María, se regía y gobernava, rescibiendo sus ynstrucciones para hazer los conjuros, tomándolas y rescibiéndolas como cosas de sanctos, y que tratava y hablava y comunicaba con el dicho armado y con los demas falsos sanctos que dezia la dicha doña María que avya y ellos hablavan por su boca della, estando sin sentido y como muerta, echada sobre la cama; de todos los cuales tratos, hablas y conciertos de exorcisar está testificado por fray Alonso Gasco y fray Pedro de Toro y fray Francisco de la Cruz, quemado, lo cual es cosa muy larga y prolixa para decirse por menudo, mas que el dicho reo se quedava en casa de la dicha moça doña María algunas y muchas noches a velar y guardar, durmiendo en un estrado junto a su cama, y que una noche avía tenido copula carnal con ella y la avía corrompido y avido su virginidad y se avía hecho preñada, y el reo echava la culpa del preñado al demonio, diziendo quel confesava a su madre y hermanas y les daría a entender por libros como podía el demonio empreñar sin que la muger lo entendiese ... y porque la dicha doña María dixo a cierta persona, «mira vos lo que debe un hombre a una muger que la adonzella, eso me deve a mi Luis Lopez», y el reo sabiéndolo, yndignadado contra ella, le dió muchos acotes con una disciplinas piernas y braços, descubriéndole sus verguenzas, de lo qual ella, yndignada y raviosa, quando después la conjuraron, se dió muchos golpes en la barriga hasta que vino a malparir, y en este tiempo era su confesor y la confesava muy a menudo este reo ${ }^{38}$.

38 AHN. Inq. Lib. 1027, ff 118v-119.

Proyección internacional de la iglesia hispana Hispania Sacra 51 (1999) 
Esta información que manejan los inquisidores, es recogido pues «... de todos los cuales tratos hablas y conciertos esta testificado por fray Alonso Gasco y fray Pedro de Toro y fray Francisco de la Cruz». Y María Pizarro, obviamente. Veámos de dónde se extrae lo que se asevera:

- Que fue el principal exorcista, lo dice Toro en su primera declaración. El tribunal anota. Pero Toro fue parte del segundo grupo de exorcistas, por ende sus afirmaciones sobre López son mas bien producto de ese conglomerado de datos confusos que se percibe en sus declaraciones. Además está el imponderable, como anota M. Pizarro, de los dominicos alcanzados por el brazo de la inquisición, de envolver a los jesuitas.

- Fue el primero en decir que era angel el demonio. Esto lo recoge el tribunal de la primera declaración de María, no corroborado por los otros testimonios, que argumentan que esta actitud se tomó en el segundo grupo. De hecho - lo dice Toro-cuando ella le expresó este parecer, López se enfureció.

- Las relaciones amorosas entre ambos y el embarazo de María. Esta basado en las primeras declaraciones de ella, que luego las desmintió. El tribunal lo presenta no como lo había propuesto y evidenciado antes: como un asunto complicado, donde los testimonios se contradecían.

- Que el aborto fue producto de la irritación de M. Pizarro por una discusión con López. Expresado por ella, también lo había rectificado, argumentando que con aquello trataba de justificar su aborto. Puede ser ubicado en el contexto del anterior punto.

Asi, lo que se recoge es lo encontrado entre líneas de los testimonios anteriores, que además se los presentan como un todo orgánico, cuando en la práctica no lo es. Por el contratio, fruto de un contexto de marchas y contra marchas de declaraciones.

La fase informativa que se lleva a cabo, puede dividirse en tres partes, bases de las proposiciones que haga el fiscal Alcedo contra él: lo primero tiene que ver con la información ya tenida, es decir lo revisado de las declaraciones de los procesos de $1571-76^{39}$. Lo segundo es el análisis de sus papeles y cartas que se le encontraron al secuestrar sus bienes. Lo tercero que se revisa será

39 Cf Relación del proceso contra Luis López AHN, Inq Lib 1027 ff $118 v$-125v. Aqui solo presentamos conclusiones del análisis de los procesos anteriores y su implicación en el de López. Para mayor información Cf F. ARMAS ASIN, «Apuntes para el estudio de un heterodoxo del Perú. Luis López SJ» (Pro-manuscripto). Universidad de Navarra. Instituto de Historia de la Iglesia. Diplomatura de Historia de la Iglesia en America Latina, 1997. 
finalmente los testimonios de personas que se presenten a declarar -dentro del mecanismo legal que posibilita la acumulación de delaciones y acusaciones-. Veámos lo segundo y tercero.

B) Entre los papeles que se le secuestra se detecta la actitud que ha demostrado ante temas importantes a lo largo de su estancia en Indias. Por ejemplo, como jesuita que es, su posición ante el tema de la bula in Coena Domine. "Yten, parece por ciertos papeles escriptos de su mano que se hallaron en su poder, que acá en las Yndias cualquiera sacerdote del nombre de Jesus pueden absolver todos los casos de Ia bulla de la cena, por sus privilegios ...» Incluso se presentó un testigo a declarar sobre el particular «y está testificado por un testigo, que absolvió a cierta persona en que mostraba no tener uno de los artículos de la fee por cierta cosa ...».

También se le rastrea su posición acerca del sacramento del matrimonio «... e assimismo a dicho y sustentado que para ser valido un matrimonio basta la voluntad y consentimiento de los contrayentes expresados por palabras de presente, en presencia del parrocho que por el concilio tridentino se requiere de exsencia del matrimonio queste presente, aunque la tal presencia sea forçosa y violenta, y que no se requiere el consentimiento de tal ministro, sino sólo su presencia, aunque esté allí forçado, con tal fuerça que fuesse miedo que cayese en constante varon, como si lo tuviese con un puñal a los pechos; y por su horden se avía hecho cierto matrimonio en el Cusco, que se hizo por fuerça y sin consentimiento del parrocho» ${ }^{40}$

Propiamente de la lectura minuciosa de los papeles encontrados, se ubicaron documentos realmente comprometedores.

Asimesmo le haze cargo el fiscal de un quademo de quarto de pliego, escripto de su propia letra, en el qual habla y apunta cosas muy graves contra su magestad, contra los obispos y prelados de la Yglesia, contra los estados religiosos y contra su propia orden y religion, contra el virey e audiencias, y dize el fiscal que todo es con yntento de desacreditar e ynfamar el gobierno espiritual y temporal que ay al presente en estos rreynos para alterarlos y levantarlos ${ }^{4}$.

El documento que encuentra el fiscal es nada menos que el cuaderno que escribe a petición de Plaza, para cuando ellos vayan a Roma. Lo que significa juicio sobre el gobierno temporal sonará ahora como lenguaje rebelde. Las críticas al estado religioso, la manera de vivir de ciertos prelados, etc., sonaran como faltas graves al estado religioso. Las aguas estaban muy tormentosas

40 Relación del proceso...119-120. Cf además MEDINA, o.c. p 101 .

41 AHN, Inq Lib $1034 \mathrm{f} 154$. Cf además MEDINA, o.c., 104.

Proyección internacional de la iglesia hispana Hispania Sacra 51 (1999) 
como para permitirse ver estos papeles con otros ojos. El Santo Oficio remitiría luego el cuaderno al virrey, para que diese su parecer. El lo devolvió con un análisis detallado y una carta a Felipe II:

Abía cerca de un año que los inquisidores prendieron al maestro Luis Lopez, clérigo de la Compañia del nombre de Jesus, que vino con los primeros de esta horden que V.M. mando venir a estas provincias doce años ha y de los que más opinión y crédito tenía entrellos, y con los demas papeles que se tomaron se halló un cuaderno de su letra en que estaba escrito el memorial de capitulos que con esta será autorizado del secretario del Sancto Officio, contra el derecho que V.M. tiene a este estado de las Indias y govierno destas provincias, que V.M. alla y sus ministros acá tenemos, el cuál habiéndose visto por los Inquisidores y entendido tocar a V.M. y al derecho y govierno destos reynos y el daño de sembrar y persuadir dello para que yo la diese a V.M. y se previniese lo que fuera necesario y combiniese, por lo cual mandara ver la libertad con que algunos destos tratan las cosas de vuestro real servicio y la ambicion y sobervia de que siempre me pareció tener alguna parte este clérigo, con que quería meter la mano y tratar de vuestro reales derechos y de lo que ni está a su cargo ni debe tratar de meterse y, como fue muy acertado el mandarme V.M. en mis instrucciones que fuese mirando bien como procedían estos padres y que hasta estar enterado dello se les fuese a la mano en el estenderse y fundar muchas casas ${ }^{42}$.

Estamos ante un documento polémico, sobre todo para un Toledo que defiende a rajatabla el Patronato Real y no permite intromisiones de ninguna especie.

También se le encuentran otras cartas comprometedoras

Asimesmo, le haze cargo de una carta que la fecha dize pues en Roma, escripta de su propia letra y mano, por la qual dize el fiscal que consta claramente la fautoria y levantamiento de fray Francisco dela Cruz ${ }^{43}$

Hasta aqui brevemente el segundo nivel de las proposiciones contra él.

C) Lo tercero tiene que ver con los declarantes que se presentan. Será un apartado muy especial, que levará a que el Tribunal lo acuse, además, de delitos de Solicitación. Se presentan varias mujeres aduciendo que las solicitó alguna vez. Veamos brevemente la relación:

42 AGI. Lima. 30. Cuaderno 3, f. 195 y ss. Dividió su réplica al texto en cuatro apartados: capítulos contra el rey y sus derechos a Indias; capítulos contra el Virrey y gobernadores; contra las audiencias y corregimientos; y sobre cómo remediar los males. Cf. «Lo que responde el Virey del Perú, don Francisco de Toledo, á los capítulos del Maestro Luis lópez...» En: «Capítulos hechos por el Maestro Luis L6pez...», en Codoin, t. 94., pp. 486-525, con el famoso cuaderno del jesuita.

43 AHN. Inq. Lib 1027, f. 122 
Depone contra este reo una María de Morales, muger de Juan de Saavedra, de hedad de veinte e tres años, que estando enferma de dolor de costado, confesándose con este reo, quexándose del dolor, el reo baxó la mano hasta ponerla sobre el estomago... y aunque hico fuerça para quitarsela, no pudo, y ella pidió un jarro de agua, y ahi cesó la confesión.

Asimismo depone una Geronima de Horozco, muger de Juan Gutierrez de Hernandez, de hedad de veynte y siete años, que en medio de la confesión, acusándose ella de sus pecados, la solicitó a actos y palabras amorosas ...

Asimismo, testifica contra él doña Joana de Vera, muger casada, de hedad de veinte y seis años, que entrando a un confisionario a confesar con el reo, le dixo muchas palabras amorosas y aficionadas, muy ocasionadas para tal fin, y luego inmediatamente la confeso, y esto le aconteció mas de seys veces ...

Asimismo testifica contra este reo doña Ysabel Pacheco, muger de Manuel Correa, de hedad de veynte y siete años, que estando en el confisionario antes y despues de la confesión, le dixo el rreo muchas palabras aficionadas y descuidadas ...

Testifica asimismo contra él Francisca de Salinas, muger casada con un mercader, que se llama Antonio Xuarez de Medina, de hedad al presente de veynte e quatro años ...44.

Asimismo se consigna aquí lo expresado por él en Cusco y que lo había Ilevado al Tribunal: «Asimismo esta testificado de que tratando de la sentencia de fray Francisco de la Cruz dixo que el Fray Francisco de la Cruz estava loco, y que siendo loco lo habían hecho herege». También dicen los inquisidores que testificó «contra el fray Juan del Campo, que ha sido provincial y al presente es guardian de San Francisco, que dixo el reo a cierta doncella que tenía alguna voluntad de ser monja, que las monjas eran gente perdida para la Yglesia « ${ }^{45}$. Asi como alguien que comentó que él «a afirmado que el juramento de secreto que se toma en el Sancto Oficio, que no obliga».

Con estas declaraciones adicionales el fiscal consideró que tenía mas que pruebas suficientes contra Luis López. Las declarantes particularmente lo habían comprometido, arguyendo problemas de solicitación ${ }^{46}$. Con toda esta información en la mano, vista por los inquisidores y consultores, asi como por el Ordinario, se mandó ponerlo preso en las carceles del Tribunal.

El fiscal presentó nada menos que 42 proposiciones de acusacion. Se recogían los tres niveles de análisis que hemos revisado. Así, ser principal exorci-

44 AHN, Inq Lib 1027 ff 119-122.

45 AHN, Inq Lib $1027 \mathrm{f} 120$.

46 Ocurridas probablemente antes de su partida de Lima en 1570 (al menos las declaraciones de Francisca de Salinas y Gerónima Horozco dan ese indicio), aunque quizá también en otras de sus eventuales estadias en Lima.

Gerónima de Horozco se presentaría también a declarar contra Miguel de Fuentes, por solicitación. De aquel texto sale la presunción que habla de 1568 o 1569 . Maurice BIRCKEL,»El Padre Miguel de Fuentes SJ y la Inquisición de Lima». Historia y Cultura 6 (1972) 18-19.

Proyección internacional de la iglesia hispana Hispania Sacra 51 (1999) 
zador, creer que había un angel bueno, las cartas comprometedoras, el crímen de solicitación, etc.

Sobre el creer que el angel era bueno, ser el principal exorcista, y tener relaciones con María, hemos visto que se recogen de la información existente en los archivos del Tribunal. Una información basado en contradicciones evidentes, un solo testigo, etc. el Fiscal lo acoge como proposiciones de acusación, como material a investigar.

Respecto a su doctrina sobre el matrimonio, la Bula de la Cena, faltas al Santo Oficio, etc., son producto de los testigos que se presentan. También se recoge como material para investigar sus papeles.

Una vez llamado a declarar dirá respecto a todo eso: sobre el asunto del matrimonio que celebró en el Cusco lo hizo canónicamente y dentro de las normas tridentinas, por tanto no existe falta. Sobre la afirmación hecha por un testigo, de haber dicho que no existe nada de malo en ocultar cosas al Santo Oficio, contextualiza sus palabras: había sido en Sevilla, en una reunión de jesuitas de su Colegio, que analizando el edicto sobre denuncias de solicitación, se pusieron reparos en algunos de los puntos a denunciar, y que él opinó sobre en qué casos hacerlos y en qué no ${ }^{47}$.

Sobre los privilegios de la Compañia en la Bula de la Cena lo defiende, sin más, pues es un viejo reclamo de la Compañia «... era verdad que él avía dicho que la Compañia tenía privilegio de absolver de los casos de la bulla de la cena, pero que en particular del caso de la heregía les esta proyvido por su general, fuera de la prohibición del Sancto Officio». Los jesuitas a lo largo de la década habían defendido este privilegio, y ciertamente el Estado -en defensa de su Regio Patronato- se los había negado.

Con respecto al matrimonio volverá a decir que efectivamente estando los contrayentes de común acuerdo y habiendo dos o tres testigos, la posición del cura poco importaba, teniéndose cuidado en cumplir con todos los demás preceptos del capítulo tridentino sobre el particular, y que esta opinión la ha «tenido con algunos autores, como son Alonso de la Cruz y otros leyentes modernos».

Sobre los escritos aclara varias cuestiones: la carta a Roma, lo hizo a instancia del doctor Plaza, y entendida dentro de una reflexión sobre las Indias. Sobre el escrito que el Fiscal sospecha tiene que ver con Cruz, dice que no es asi, pues fue hecho para el doctor Barros, de la audiencia de los Charcas, bajo el seudónimo del sacerdote Dindimo a la Diosa Cibeles, y escrito aparentemente desde Roma, para escapar a la censura de cartas que imponía el Virrey.

47 AHN. Inq. Lib 1027, f. 126. 
Además que Barros tenía problemas con Toledo. En este contexto, asume lo expresado.

Respecto a las denuncias de solicitación que se le presentan argumenta que efectivamente se acuerda haber hablado muchas palabras aficionadas, que mal planteadas habían generado confusiones y malentendidos. Reconoce sin embargo que estuvo enamorado de algunas «con doña Catalina Marroquin ... la tuvo particular aficion». $O$ con Petronila de Meneses.

Sobre María Pizarro, reconoce -como lo había hecho en la carta de descargo de 1576-, que la exorciz6 alguna vez, con las respectivas autorizaciones, pero nunca tuvo otro tipo de relación con ella. «... y dize que era verdad que parescía que la dicha doña María estava preñada y se dava golpes en la barriga y que él se lo estorvava, teniendo sospechas que estava preñada de Diego Martinez con quien la dicha doña María pretendió casarse, y que era verdad que la dicha doña María se le avía quexado porque la tratava mal y le avía dicho que le avía [quitado] su virginidad y que él le respondió que mentía y que ella avía callado ...».

De las proposiciones hechas, y a pesar de las limitaciones de la documentación, en el tema de María es muy difícil de afirmar que López creía en angeles y menos que sostenía amores. Lo negará, planteando más bien que Pizarro anduvo enojada con él y embarazada de un tercer sujeto. Sobre la bula de la Cena y los jesuitas, asi como la posición sobre algunos puntos del Edicto de Solicitación, pueden ser vistos en la perspectiva de un contexto donde efectivamente ideas polémicas sobre estos temas se plantean. De allí precisamente que López no sea visto como un caso aislado. Sobre su posición respecto al matrimonio, si es posible argumentar que es un punto sólido en el cual el Fiscal se ampara. Además el mismo López lo reconoce: es de factura personal. Sometido a una discusión teológica y canónica, puede salir no muy airoso.

En cuanto al tema de solicitación y de las cartas, es un debate interesante. Los escritos lo reconoce de factura propia. Aunque contextualizadas, tanto la escrita a instancia de Plaza como la de Dindimo a Cibeles, son explosivas en sus temáticas y de hecho resultan un asunto muy delicado. Sobre los delitos de solicitación lo niega aunque reconoce palabras 'aficionadas'. No niega sus sentimientos amorosos, que ciertamente la Inquisición no juzga, pero si la solicitación en forma.

En general, se puede sugerir que eran sin duda los asuntos de las cartas las ideas politicas-, la solicitación, el tema sobre el matrimonio, y eventualmente el asunto de la Bula de la Cena o del Edicto de Solicitación, las bases mas sólidas para juzgarlo que los temas de María Pizarro. Incluso los de solicitación e ideas politicas, pueden considerarse como de primer orden dentro de un análisis de pruebas en su contra.

Proyección internacional de la iglesia hispana Hispania Sacra 51 (1999) 
Finalmente, luego de concluir con sus descargos ante el Tribunal; los calificadores extrajeron de sus escritos, los testimonios, y de sus propias declaraciones «quinze proposiciones herroneas in fide, temerarias y escandalosas y mal sonantes y contra el libre exercicio del Sancto Officio...a el estado de los religiosos» ${ }^{48}$.

De lo expresado por la carta de los Inquisidores se extrae que, depurada la etapa anterior, se pasó a considerar al reo como acusado de delitos contra el Santo Oficio y el estado eclesial. Obviamente bajo esos rubros pueden caer todos los cargos anteriores presentados por el Fiscal, de modo que no podamos nunca saber concretamente que contenían esas quinces proposiciones a diferencia de las proposiciones originales. Pero una lectura rápida del informe hace ver que los delitos de solicitación, sus escritos políticos y sus impresiones frente al matrimonio, debieron de ser los ejes claves en torno al cual giraron los últimos interrogatorios del Tribunal. Su participación en el asunto de María Pizarro -creer en angeles y revelaciones, ser un alumbrado, según la proposición del Fiscal Alcedo-, pasa a un segundo plano.

En esta nueva etapa se presentan otros testigos, sin consecuencias. Se encuentran supuestamente más papeles suyos, que analizados, motivan nuevas proposiciones. Que López las rebate sin complicaciones ${ }^{49}$.

Desechadas estas, el proceso entró en su fase definitiva. Frente a las quince proposiciones López

... presentó una petición y otras nuevas defensas con acuerdo de su letrado, las quales y las demas se acabaron de hazer..

Finalmente, y debió ser en 1581, pues la carta de los Inquisidores que dá cuenta del proceso íntegro es de 1582, visto por el Ordinario y los consultores, el proceso fue votado para que se leyese la sentencia. Fue leída en la sala del Tribunal, solamente delante de ocho padres de las Compañia, abjuró allí de levi, y luego se pasó al Colegio de la Compañia en Lima, a leerse nuevamente la sentencia, en presencia de los Padres reunidos y del notario del Tribunal, mientras se le daba una disciplina que duraba el tiempo de dos Psalmus de miserere mei, según la constumbre de la Compañía. López abjuró y empeź́ a expurgar las faltas que el Santo Oficio había fallado en su contra. Se le sentenció a regresar a España y no volver a las Indias, y allí que no pueda salir del Colegio de la Compañia donde esté acogido, durante cuatro años; y al término

48 AHN, Inq Lib 1027 f $125 \mathrm{v}$

49 AHN, Inq Lib 1027 ff 195 y ss. Cf además CASTAÑEDA, o.c., 312. Los papeles fueron encontrados en la Casa de la Compañía. No era su letra y menos eran sus ideas. 
de los cuales por otros seis no pueda salir a diez leguas a la redonda. Se buscaba el recogimiento y el expurgo, por tanto, no podría predicar en esos diez años. Dado que es sentenciado por delitos contra el Santo Oficio, el estado eclesial y sobre todo por solicitación, se le prohibe confesar mujeres perpetuamente, y a hombres por cuatro años - en el tiempo de máximo recogimiento en el Colegio-. Ciertamente, en los primeros diez años, perdería la voz activa y pasiva ${ }^{50}$.

«... Luys Lopez, con acuerdo de su letrado, y por dicho fiscal fue apelado [la sentencial y se concluyo deffinitivamente en esta segunda ynstancia»

La nueva sentencia, redujo los cuatro años de recogimiento intenso a dos, y que sean cuatro y no seis los años siguientes para no poder salir a diez leguas a la redonda. Asimismo a los dos primeros años de recogimiento se reduce el no poder confesar varones, y a seis el recogimiento sin voz activa ni pasiva ${ }^{51}$.

A petición de la Compañia se retiró al Colegio de Trigueros, en el condado de Niebla. Luego de expurgar pasaría a laborar en Sevilla, donde hallaría la muerte.

III

La Compañia de Jesus había traído al Perú la esperanza de un espiritu y comportamientos nuevos, que debía de llenar de gozo a los hombres más instruidos del virreinato, alarmados por ciertas deplorables lagunas. Sin embargo, estos pronto se dieron cuenta de los peligros de la nueva tierra. El mismo Lopez, con su natural franqueza, le decía al General Borja «son necesarios Padres de mucha virtud para los de afuera, por los peligros gravíssimo de caer como arriba digo: y principalmente en el vicio de la sensualidad, que como es poderoso y tiene tantos instrumentos nobles e innobles, haze brabissima guerra a los muy espirituales ... $\rangle^{52}$. También el Padre Diego Martinez explicaba a Plaza del problema de doctrinar solo: «Otra dificultad ay mui grande: el peligro grandísimo que ay de perder la pureza del alma y cuerpo; y digo que es extraordinario el peligro que ay y que no se remedia con estar diez ni quinze de la Compañia juntos, porque las ocasiones son grandes. Las tentaciones e im-

50 Mientras permanezca en Lima se le ordena que esté recluido en su Colegio y no diga misa los tres primeros meses. Partirá en la primera flota a Panama, y desde allí recién podrá volver a celebrar oficio. Medina, o.c., 169; AHN, Inq Lib 1027 f. 197v.

51 AHN, Inq Lib $1027 \mathrm{f}$ 197v. Una copia de la sentencia puede verse en AHN, Inq Leg 1653 exp 14.

52 Monumenta., 1 p. 329.

Proyección internacional de la iglesia hispana Hispania Sacra 51 (1999) 
bustes del demonio más fuertes que yo jamás pense ... $\rangle^{53}$. Estos temores no tenian nada de inocentes y con ellos vinieron los problemas inquisitoriales. Desde 1578 el general Mercuriano recomendaba a los suyos reforzar la disciplina: «También he visto la relación del auto de Inquisición [el de Cruz] que V.R. me embio, y por él veo la obligación que tienen los nuestros de vivir con todo recato y cuidado sobre sí, para que no caigan en semejantes inconvenientes ...» ${ }^{54}$. Esfuerzo inútil, porque inmediatamente después entraría a la Inquisición López. Luego Pedro de Cartagena y Miguel de Fuentes ${ }^{55}$. En 1568 la primera expedición jesuita, con Lopez, Fuentes y Portillo, llegaba a Lima en medio de la aclamación general. ¿Quién hubiera pensado entonces que cuatro de los siete primeros misioneros jesuitas se verían envueltos en problemas con la Inquisición! ${ }^{56}$ ¿ ¿Que había ocurrido?

Luis López había sido un misionero denodado y había logrado evidentes frutos de labor a poco de su llegada. Viajero incansable, se distinguió además por los cargos y títulos que ostentaba. Pocos entonces sospecharían que el sacerdote se vería envuelto en líos de distintos calibres que lo terminarían llevando a la Inquisición. Crítico incansable del estado de cosas en el Nuevo Mundo, no tuvo problemas en denunciar las irregularidades de prelados y religiosos, así como tampoco en oponerse, como muchos del momento, al autoritarismo de la administración colonial frente a cuestiones como la Bula de la Cena, el problema de doctrinas, etc. Tuvo la suerte o desgracia de estar presente en el surandino cuando se dieron los enfrentamientos finales con Toledo en el cierre de los Colegios de la Compañia. Hombre crítico, como Bartolomé Hernandez por ejemplo, tuvo constantemente palabras ácidas para Toledo, viéndolo como el vice Patrón en esencia, tratando por todos los medios de cortar las autonomias de las ordenes, particularmente de la Compañia. Siempre anduvo quejándose cuando hombres como Portillo le dispensaban cierto trato amical al virrey. Tal vez por eso fue poco querido por la administración colonial, y los asuntos de María Pizarro habían puesto por otro lado sobre alerta al Santo Oficio sobre el sacerdote. En 1578 López era llamado a declarar como en 1579 lo sería Fuentes ${ }^{57}$. Se estaba en la cúspide del enfrentamiento con Toledo -1578 es el año del cierre de colegios y el docto Acosta trataba de poner orden a su grey. Por otro lado además, en España los asuntos de Llerena y el alumbradismo en que supuestamente estaban complicados jesuitas, volvía

\footnotetext{
53 Monumenta., II p. 36.

54 Monumenta., II p. 522

5s $\mathrm{Cf}$ al respecto Birckel. o.c.

s6 Ciertamente de ellos los procesados serían Fuentes y Lopez. Denuncias y observaciones merecieron el resto.

57 Ambos habían participado en los exorcismos de 1570.
} 
sobre ellos una nube de sospechas. En ese clima se produjo la noticia de las detenciones de los jesuitas, cayendo como una bomba entre los padres.

Según se puede extraer de la lectura de la sentencia, López terminó siendo procesado básicamente por los delitos de solicitación, de faltas graves al Santo Oficio, al estado eclesial, por palabras y escritos que comprometían la politica real, etc. Sustancialmente es posible ver que poco cambia, dada la naturaleza de las palabras de los Inquisidores, entre la acusación de quince proposiciones y la sentencia. En esencia parece que primó una postura tendiente a castigar estos delitos de acuerdo a los procedimientos del caso por el Tribunal.

La sentencia se centraría rigurosamente en el recogimiento del reo -luego de abjurar-. Se busca como es obvio la reconciliación. Lo nuclear dentro del recogimiento está dado por el no confesar mujeres y luego de un tiempo confesar varones. Además -y por extension del recogimiento- pierde en el lapso de tiempo del expurgo, la voz activa y pasiva dentro de su Orden. Vista en esta óptica la sentencia -con centro en recogimiento y el tema de la confesión-uno puede darse cuenta que la Inquisición penó la solicitación, las palabras malsonantes, las ofensas al estado eclesial, y en general todo lo que estuviera dentro de su competencia. Pero no penó exorcismo ni supuestos alumbradismo del jesuita - que estaban incluido dentro de los procesos de María Pizarro y los dominicos, $\mathrm{y}$ que por añadidura pudo comprometérsele-. Las penas apuntan a otra cuestión y no a sanear problemas de alumbradismo -que además el reo siempre las nego, por tanto la reconciliación no hubiera tenido los cauces que presentó- Ciertamente el alumbradismo nunca fue explicitado en tal por el Fiscal, pero hablándose que López creía en un angel bueno, se estuvo a un paso.

Como se refería en algún momento, la poco solidez en que se basaban tales presupuestos, unido a la negativa de López a aceptarlos, debieron de apoyar la postura de dejarlos de lado finalmente como motivo para sentencia. Desde un punto de vista riguroso los temas de solicitación - con testigos y declaraciones del reo en el sentido de aceptar ciertos enamoramientos-, asi como los papeles encontrados y sus ideas sobre el matrimonio, etc., fueron los puntos de sentencia ${ }^{58}$.

58 Por otro lado, cuando el 12 de noviembre de 1579 declare en el proceso de Miguel de Fuentes, Paula Acuña, mostrará hasta qué punto había impactado en la sociedad limeña el asunto:

«...dixo que dō̄a Francisca Pizarro diziendo que era hija de confeșión del padre Portillo estava preñada del dicho Portillo... y la querían traer a parir a su casa y questava preñada de] provincial Portillo...»

Lo cual corrobora lo expresado anteriormente: lo poco confiable de muchos testimonios. Birckel o.c., 4l. Fuentes al igual que López, procesado por solicitación y alumbrado, terminó sentenciado por solicitación solamente.

Proyección intemacional de la iglesia hispana Hispania Sacra 51 (1999) 
Lo expuesto apunta a tratar de comprender en términos absolutamente procesales el resultado del auto condenatorio. Es una posible respuesta. Otra puede ir acompañada de una caracterización contextual.

Decíamos que en 1579, en el momento cumbre de los procesos a los jesuitas, las relaciones entre estos y Toledo estaban en un punto álgido. Después de varias escaramuzas la ruptura es consumada a fines de 1578 , cuando el virrey ordena el cierre del Colegio de Lima, y la Compañia, que no admite tal injerencia, acaba por llevar el asunto al monarca ${ }^{59}$. En este contexto el paisano de Toledo e Inquisidor, Serván de Cerezuela, le lleva los papeles de López, notificando las intromisiones del padre en el orden temporal ${ }^{60}$. En carta a Felipe II, del 27 de noviembre de 1579, vimos como el Virrey había reaccionado. Así el proceso, como ya lo ha expresado Egaña, se mueve entre el nivel de lo político y lo estrictamente inquisitorial, complicando la posibilidad de poder explicar cuestiones como el derrotero del proceso en términos absolutos del fuero del Santo Oficio. Ahora bien, esto no debe llevar inmediatamente a deducir la mano de Toledo en el por qué López fue procesado. Ciertamente, después de la detención del jesuita, la de Miguel de Fuentes se debió única y exclusivamente a razones judiciales ${ }^{61}$. Tratándose de dos adversarios del sistema de doctrinas, y particularmente López, un crítico de su persona, éste podria haber visto en el disgusto de los jesuitas una forma de justicia inmanente. No obstante, ningún indicio hasta el presente nos permite adelantar que don Franscisco haya intervenido personalmente en la instrucción abierta salvo su parecer sobre los textos de López. Obviamente esto no exime de recalcar la importancia del hecho, pues demuestra en forma convincente el grado de atención que despertó en el Virrey el proceso, y probablemente la pre-disposición del regocijo ante el jesuita en desgracia. De todas maneras el desenlace final de la sentencia, recalcando la importancia del delito de solicitación sobre otros delitos, lleva a creer que existen otros elementos complementarios en el panorama.

Por aquella década ocurrían los sucesos de Llerena, los asuntos de María Pizarro, y lo que el Virrey llamó la «suprema conspiración en Yndias» entre dominicos alumbrados y lascasianos (Gasco, Toro, Cruz, etc.), que en alguna forma comprometía a toda la Compañia. Además, los jesuitas eran hacia esos días no muy bien vistos por hombres como el dominico fray Miguel Adrián, celoso defensor de la pureza de la fe y allegado al Santo Oficio.

En esos momentos se produce el arresto de López y más tarde de Fuentes. Tras esto los jesuitas se esperaban lo peor, intentando en lo posible amortiguar los efectos desastrosos que tales acontecimientos iban a causar en la joven

59 VARGas UGARTE, Historia de la Compañia de Jesús en el Penú I,cap DX ; EGAÑA, o.c., 115-186.

6n Ibid., 153.

61 BIRCKEL, o.c., 79 . 
provincia y en el renombre de la Sociedad en España. Aquaviva, nuevo Prepósito General, escribía así a José de Acosta el 1 de agosto de 1581:

No me maravillo que cause en V.R. la afflictión que scribe un golpe tan de sentir como la prisión de esos dos; conviene mucho, de más del continuo cuidado que acá y allá ay de enconmendar el suceso a Nuestro Señor, que V.R., como siempre lo ha hecho, busque todo los medios posibles para que esos señores del Sancto Officio miren lo mucho que importa el buen crédito de la Compañia y no den lugar a mas publicidad; y quanto puedo encargo a V.R. se procure que, ya que en estas partes no se puede escusar lo que averse hecho con modo tan público la Compañia avrá padecido, no se le de otra mayor afrenta y travajo enbiando a algunos desos dos a España, pues si hubiesen de estar reclusos algun tiempo, seria menor daño a la Compañia que lo estuviesen ai donde sus cosas se saben ...62

José de Acosta era consultor del Santo Oficio. Con un intervalo de algunos días, en una carta al Provincial Piñas, el Prepósito parece decidido a castigar severamente a Lopez:

Muy fuerte golpe ha sido para la Compañia, especialmente en esas partes, lo de Luis Lopez y Fuentes, y aunque cuando esta llegue, creo se avrá sentenciado, me ha parecido necesario escribir a V.R. ...supuesta la diligencia con que se ha siempre de procurar por todos quantos medios se pudieren que no aya publicidad, me he resuelto en despedir a Luis Lopez, pues no es justo que quien tan indignamente se ha avido en la Compañia, quede con tanto daño della...63

En ese momento ya el Tribunal habia fallado contra López aminorando notablemente, luego de la apelación, la pena. Y la solicitación -delito común-es el nucleo de la sentencia. Libre de toda acusación de alumbradismo. En medio de la extrema inquietud que conocían por aquellos días los miembros de la Sociedad de Jesús, la sentencia del Tribunal cayó como un verdadero alivio. Incluso antes de recibir un informe detallado, Aquaviva se apresura a escribir a Piñas:

...Ha sido cosa que no sabría encarecer a V.R. el consuelo que me ha dado; plega el señor sepamos agradecerle misericordias tan grandes como siempre haze a la Compañia; y porque el orden que yo embie a V.R. en la de 7 de agosto, así para despedir a Luis Lopez como para embiar aca a Fuentes era persuadiendome saldrian muy de otra manera, aviso a V.R. que siendo assi el suceso...no aver inconveniente...queden...64

62 Monumenta, III pp. 31-32.

63 Monumenta, III pp. 40-41.

64 Monumenta, III p. 92.

Proyección intemacional de la igłesia hispana Hispania Sacra 51 (1999) 
Con más retraso, en 1583, confirmaba el general la enorme deuda de la Compañia con el Santo Oficio: «Mucho devemos a la divina bondad y a la de esos señores Inquisidores del Sancto Officio en la tempestad de los dos presos aya pasado con menos pérdida de la que se temia» ${ }^{65}$. En 1585 , velado, Juan de Atienza recordará lo sucedido «...porque a la Inquisicion, aunque en todas partes la tiene la Compañia la mucha obligación que todos sabemos, en esta parte se la tiene mayor por las cosas que V.P. sabe.... ${ }^{66}$

Pero el mismo Tribunal había recibido órdenes expresas de la Suprema respecto a los jesuitas «su Señoria Ilustrísima nos manda en su carta hecha en Toledo en 25 de agosto de 1580 que tengamos quenta con honrrar y favorecer las cossas de la Compania... ${ }^{* 7}$ Se puede, pues, tener por seguro que la Suprema, y sobre todo el Gran Inquisidor, Gaspar de Quiroga, tuvieron una Influencia en el desenlace del proceso de Luis López. De hecho consta la benevolencia de Quiroga en los asuntos de López ${ }^{68}$. Como dice Aquaviva «...la protección tan de padre que tiene a nuestras cosas...» ayudó al desenlace.

\footnotetext{
«Al illustrisimo de Toledo se ha escripto, y si agora se escribiese en particular a cada uno de esos señores del Sancto Officio, haziéndoles gracias de la merced que se nos hizo en no dar tanta publicidad allende de que ya sería tarde...»
}

Los jesuitas habían intentado que el proceso fuese llevado directamente a Madrid, y resuelto allí sin ser tratado por el Tribunal limeño. Pero dado que era imposible que el Tribunal General se inmiscuya en un caso de primera instancia, la tentativa fracasó ${ }^{69}$. Sin embargo recurrieron a Gaspar de Quiroga. El mismo Consejo de la Suprema y General -Tamin̄o, Manrique, Salazar y Llano de Valdez - le escriben a éste en torno al caso, y comprensivo responde el Inquisidor General: «En lo que toca a Luis Lopez, lo que puedo decir es que me dicen personas a quien debo creer que es buen religioso y muy diferente de como lo pinta el Virrey, el cual se ha portado con pasión contra la Compañia, y es razón tener respeto a esto y tratar bien a Luis Lopez en todo lo que sufriere de justicia, y tratarle con decencia que se debe a esta Santa Compañía» ${ }^{70}$. En ese sentido el Consejo escribirá a su Tribunal limeño para «Que se tenga mucha cautela en lo que toque a la Compañía ( $^{71}$.

\footnotetext{
65 Monumenta, III, p. 299.

66 Monumenta, III p. 595.

67 BIRCKEL, o.c., p 86; Castañeda, o.c., p 312.

68 ASTRAIN, o.c., III, p. 174; Egaña o.c., 268-270

69 HUERGA, o.c. III p. 192

70 HUERGA, o.c., III p. 193.

7) AHN, Inq lib $1027 \mathrm{f} 69 \mathrm{r}$.
} 
Y esa actitud de Madrid se puso de manifiesto por ejemplo cuando Plaza, al ser llamado a declarar ${ }^{72}$, expresó algunas frases contradictorias, luego de haberse cerrado herméticamente a hablar. López reaccionó pidiendo audiencia para denunciarlo (enero de 1581$)^{73}$. Lo acusó de decir «que los señores inquisidores estaban en peligroso estado por razón de su oficio... que creía, que según estaban las cosas del Santo Oficio con tanto rigor (en esa década de los años setentas), que si Jesucristo nuestro Señor estuviera en el mundo, que o lo quemarían o lo ensambenitarían». Según él, se lo había dicho en el Cusco, en 1577. Como Plaza luego de declarar había embarcado en Junio de 1579 para México (declaró en el primer semestre), los inquisidores dieron curso a la denuncia ante el Consejo, para encausarlo. Pero la respuesta fue «no procedan contra él», frenando al Tribunal limeño en extender el drama.

Así no solo la Compañía gestionó por los procesados, sino el mismo Consejo lo hizo también, presionando ambos sobre el Tribunal de Lima.

Pero tampoco deberíamos olvidar la influencia que ejerció José de Acosta en la evolución de los acontecimientos. En su deseo de preservar los intereses de la Compañia, el nuevo general había llamado a todas las puertas y si la del cardenal Inquisidor no fue la menos rápida en abrirse, el general -como ya vimos en una de las cartas - acudió en el pais al influyente Acosta. Sus cualidades de intelectual, diplómatico, sus buenas relaciones con la Inquisición, del cual era consultor, hacían de él un personaje clave. Su misión no deja muchas trazas sobre el papel, sin embargo sabemos que su diligencia no quedó sin efectos, al menos así nos lo dice una carta del encargado general al mismo José de Acosta:

72 AHN, Inq Lib 1034 259r-v. Con Plaza todo hacía presagiar que su estrella continuaría en ascenso, pues esperaba acompañarlo a México, cuando en 1578 se le nombró Visitador de esa Provincia. «V.P. le acompañara (a Plaza) hasta México». Mercuriano a López, 31 de enero de 1579 Monumenta Mexicana, I pp 412-413. En las mismas instrucciones a Plaza, Mercuriano apunta el nombre de López como futuro Consultor en México. Monumenta Mexicana, I p 418. Pero cuando se entere de su arresto, reacciona y le dice al Vísitador «...habiendo tenido relación mas en particular del estado de la causa del Padre Luis López que, en caso que hubiese ido con V.R. a México, no nos parece conveniente que lo tenga por compaffero suyo...parece con dogma de consideración, suspender esto, hasta que sepamos cuál es la sentencia del Santo Oficion. Monumenta Mexicana, I p. 513.

Plaza mismo, ante el arresto, se creerá en peligro. Adelantará sus preparativos y marchará presuroso a México, según la Inquisición.

73 En verdad, en prisión, López se siente abandonado por amigos como Plaza. Expresa «que sus hermanos Ie habían vendido».

«Confiesa que dijo algunas veces, estando afligido, que sus bermanos le habian vendido, y que si no fuera por el decoro de su religión, que él hiciera que estuvieran algunos en este Santo Oficio como él, y que lo dijo parte por aflicción y parte por ciertas cosas que tiene declaradas contra dos teatinos, que el uno vino por Visitador de esta tierra (Plaza), y declaró el reo qué sabía contra el Visitador cuando supo o entendió que sería ido a Nueva España, como lo es».

Proyección internacional de la iglesia hispana Hispania Sacra 51 (1999) 
Officio que hizo con los señores Inquisidores. El oficio que V.R. ha hecho, tan como hijo de la Compañia, para que estuviese la menor nota que fuese possible las cosas de Luis Lopez y Fuentes, tengo yo mui bien entendido y de entrañas se lo agradezco...

Los inquisidores limeños supieron pues mostrarse conciliadores frente al proceso de López. Sin embargo, no debemos descuidar lo que antes expresábamos, vale decir, que ya incluso desde el punto de vista jurídico y estrictamente procesal los cargos de alumbradismo tenían poco sustento. De modo que habia probabilidad de una conclusión como la sucedida. Sin embargo los problemas con Toledo, el contexto de enfrentamiento de los jesuitas en el Perú, los sucesos de supuesto alumbradismo que María Pizarro había despertado en la sociedad colonial, unido a los acontecimientos de Llerena, bien pudieron, por corriente propia haber llevado los resultados a otro nivel. Sin duda, defendiendo sus propios privilegios y enojados con López por sus críticas hacia ellos, pudieron los del Tribunal empujar el proceso al nivel de Cruz. Pero no lo hicieron. La voz serena de Acosta, las recomendaciones expresas del cardenal inquisidor, y en general los cuidados que los de la Compañia pusieron en defender sus intereses, permitieron un análisis mas sosegado de lo que pasaba frente a sus ojos. Como Fuentes, López tendría mucho que agradecer los buenos oficios y las intersecciones ${ }^{74}$. Y como para redondear el proceso, fue admitida su apelación, y reducido la monta de las penas, en Lima mismo, sin tener que apelar a la Suprema. Como bien refiere el P. Egaña SJ, a propósito de la sentencia final, «no fue ciertamente ensañada y si muy suave comparada con la hoguera en que terminó Cruz su historias ${ }^{75}$.

Hacia mediados de 1582 salía del Perú López. Desembarcó en San Lúcar de Barrameda y fue llevado por padres de la Compañia a Trigueros, donde empeź su recogimiento. Fue conducido con mucho sigilo del puerto al Colegio, para evitar ni «ruido de alguaciles ni de otros ministros» según Aquaviva. Casi a poco de llegar, empieza a escribir al general, intentando explicar su inocencia y congraciar su conciencia (la primera carta es del 21 de noviembre de 1583). El 15 de junio le responde Aquaviva: «ha lastimado mucho a los que lo saben, y más a mí, conforme a la condición de mi oficio» ${ }^{76}$.

74 Gozará de algunas comodidades, como permanecer en la celda de su Casa un buen tiempo, y no ser torturado -porque ciertamente admitía algunas acusaciones^. Además, cuando se le leyó la sentencia, se hizo en presencia solamente de padres de la Compañía, cuando se acostumbraba hacerlo frente a los superiores de las órdenes, confesores, curas de parroquias,etc. Algo que notaría extrañado, años después, el Visitador del Santo Oficio Ruiz del Prado. CASTAÑEDA, o.c., p. 312.

75 EGAÑA, o.c. p. 184.

76 HUERGA, o.c., p. 555. 
Recogido, continúa escribiendo, cada vez en tono más angustiante. El 23 de febrero de 1584 el general da signos de comprension: «Mucho me consuela que en medio de sus trabajos, le dé Dios tanta conformidad con su divina voluntad tanto conocimiento de sí mismo cuanto en la suya me magnifica...». Cuando termina los dos años de reclusión en el Colegio quiere, al menos, se le destine a otro lugar para terminar su expurgo. El General responde: «El venir para acá [Roma] no se puede tratar por ahora, pero puede verse para adelante» 77 .

Mientras que para su grey en el Perú Aquaviva tiene palabras de cuidado «...[vivir] muy conformes a nuestra reglas y instituto, los quales, como al $\mathrm{Pa}$ dre Provincial escrivo, desseo yo se guarden muy exactamente en toda la Compañia, más con particular exaction y cuidado en esas partes, donde no solo ay tanta ocasión de relaxación, más se ha incurrido en ella, con tanto detrimento del buen nombre de la Compañia, consérvela Nuestro Señor por su infinita misericordia en toda pureza y abundancia de sus santos dones» ${ }^{78}$.

Luis López permanecerá hasta 1589 en su recogimiento de Trigueros. El misionero, escritor y hombre de virtudes probadas, trata de resarcirse ante los suyos mientras se esfuerza por tener una vida tranquila dedicada al trabajo y mortificaciones constantes. Desde las tierras cálidas e inhóspitas de Santiago del Estero, hoy Argentina, Alonso de Barzana, el gran misionero por excelencia, quechuista y hombre de la gran labor de las primeras horas en los Andes, le escribe el 8 de setiembre de 1588. Desde donde se encuentra, sacando adelante nuevas misiones de la Compañia, se acuerda de quien fue su gran compañero de labor en los años setenta. Es una carta hermosa y ejemplizadora de quien tiene autoridad para hacerlo. Reconoce a López como su antiguo «confesor, superior y compañero único en los reinos del Perú». Una misiva cargada de recuerdos, palabras agradables y reconocimiento a quien había hecho tanto por la Provincia del Perú.

Luis López morirá en 1599, trabajando en Sevilla, a donde finalmente fue enviado. Parece que por 1591 estaba en trámite un proceso de rehabilitación para él y Fuentes en la inquisición española, pero no se sabe más del asunto ${ }^{79}$.

El General Aquaviva hace de todo lo ocurrido tripas corazón, y como cerrando el estudio, recoge las desdichadas experiencias de los procesos contra los suyos

...y he alabado la divina bondad que todo buelbe en bien de sus escogidos, porque de la caída de los que nos han sido causa de dolor y confissión, se sirven para mayor humildad y recato de los que están en pie, que por la bondad divina son muchos, los quales

\footnotetext{
77 lbid., p. 556.

78 Monumenta II, pp. 299-300.

79 BIRCKEL, o.c., p. 77.
}

Proyección internacional de la iglesia hispana Hispania Sacra 51 (1999) 
sin perder por eso el ánimo ni acobardarse, procuran con mayor esfuerço ilustrar el buen nombre de la Compañia para que, como operarios inconfussibles, sean aptos intrumentos por quien Nuestro Señor gane muchas gentes para su Reino, sic cinim et angeli timuerunt en la caída de sus compañeros et territi purgati sunt ${ }^{80}$

80 Monumenta $\amalg$, p. 424. 